\title{
THE IMPACT OF LOCAL ON MEAT PURCHASING DECISIONS
}

\author{
A Thesis \\ presented to \\ the Faculty of California Polytechnic State University, \\ San Luis Obispo
}

\author{
In Partial Fulfillment \\ of the Requirements for the Degree \\ Master of Science in Agribusiness
}

By:

Steven McLennan

October 2014 
(C) 2014

Steven McLennan

ALL RIGHTS RESERVED 


\section{COMMITTEE MEMBERSHIP}

TITLE:

AUTHOR:

DATE SUBMITTED:

COMMITTEE CHAIR:

COMMITTEE MEMBER:

COMMITTEE MEMBER:
The Impact of Local on Meat Purchasing Decisions

Steven McLennan

October 2014

Marianne McGarry Wolf, Ph.D.

Professor of Wine and Viticulture

Andrew J. Thulin, Ph.D.

Interim Dean of the College of Agriculture, Food and Environmental Sciences

Eivis Qenani, Ph.D.

Professor of Agribusiness 


\section{ABSTRACT \\ The Impact of Local on Meat Purchasing Decisions \\ Steven McLennan}

The research examines the target market for a meat product produced by the local university. Further, desirable attributes of meat and how consumers definition of "locally produced and/or raised" are identified. A total of 290 personal interviews were completed in San Luis Obispo County, California on the consumers' willingness to purchase Cal Poly meat. Likely purchasers are found to be 31 percent of the San Luis Obispo population. The target buyer of Cal poly meat products are both male and females, who tend to be older, and make more than $\$ 60,000$ a year. Local is defined by 31 percent of likely Cal Poly Meats buyers as being grown and/or raised within the county they reside in, and also shared by residents of San Luis Obispo County. Additionally, it was found local vegetables are a more highly valued product than local meats, fruits, and wines product grown within the San Luis Obispo County.

Keywords: Consumer Perception, Local, Meat, Direct-to-consumer and Farm Direct Marketing 


\section{ACKNOWLEDGMENTS}

The idea of pursuing a masters in Agribusiness never entered my mind until three years ago. When the idea became a reality, it could not have been for the support, encouragement and endless love from individuals in my life.

Dr. Marianne Wolf, I can not express my graditude for your unwavering support and encouragement throughout the entire thesis process. I enjoyed every step and could not imagine going on any acedemic adventure without you in my corner.

Dr. Andy Thulin, you have been a mentor in my life that every student deserves. You have pushed, stretched and challenged me to become a better man, student and employee. I look forward to continuing to calling you my friend.

Dr. Eivis Qenani, I thank you for all the help and advice that you provided me during my time at Cal Poly. Every interaction was cherished and will be remembered forever.

Lastly, to my mother and father, Linda and William McLennan. I can not put into words how appreciative I am of your endless love and support. I thank you for the morals and values that you enstilled in me over the years. Thank you for everything that you have done. 


\section{TABLE OF CONTENTS}

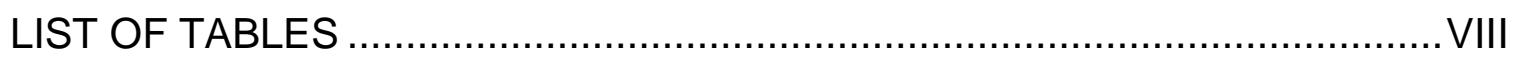

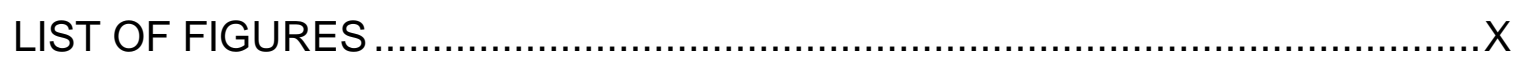

\section{CHAPTER}

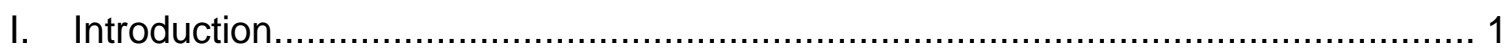

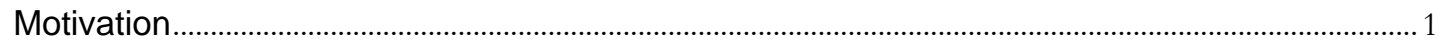

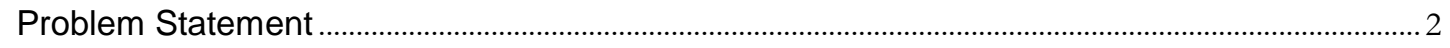

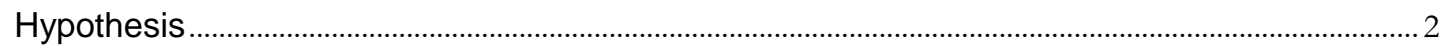

Hypothesis 1 ...................................................................................................................

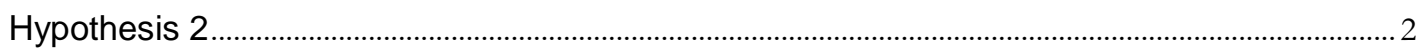

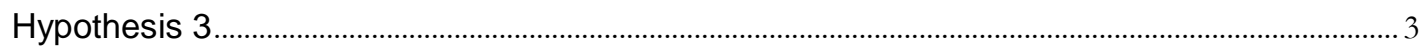

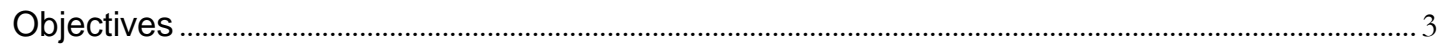

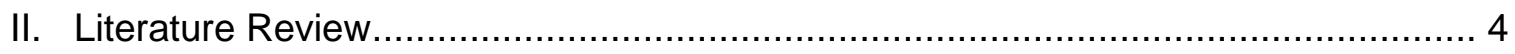

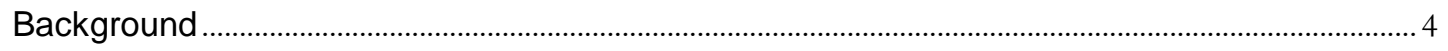

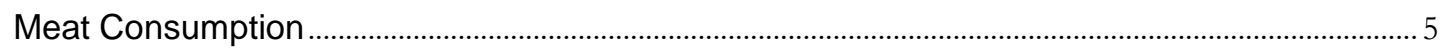

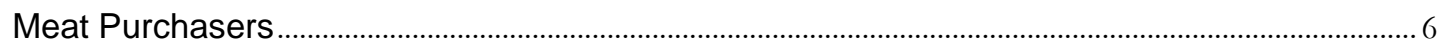

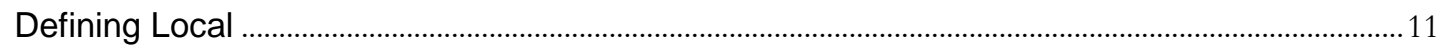

Value of Local ...............................................................................................................................12

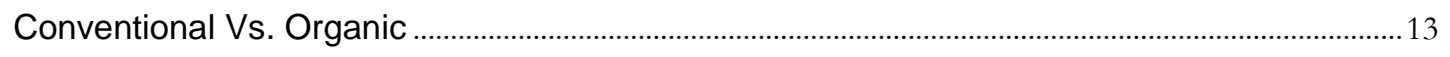

Farmer's Markets .......................................................................................................................................

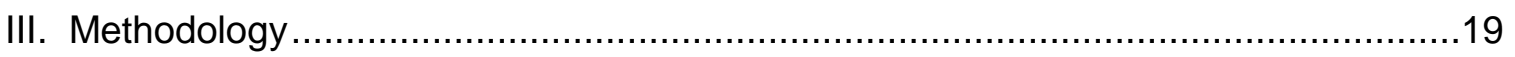

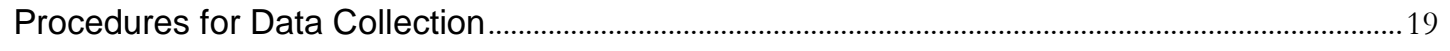

Procedures for Data Analysis .......................................................................................................................2

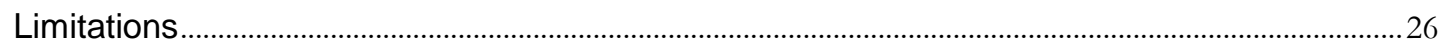

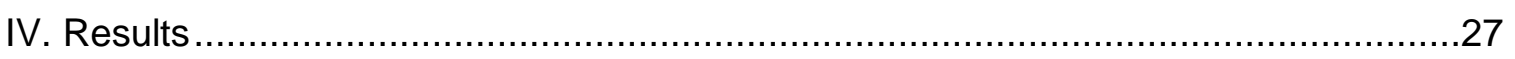

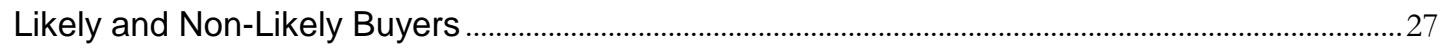

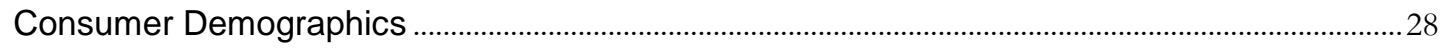

Purchasing Habits ........................................................................................................................................33

Meat Attributes Consumers Desire ......................................................................................................37

Consumer Reaction to Cal Poly Meat Product Concept......................................................................4 40

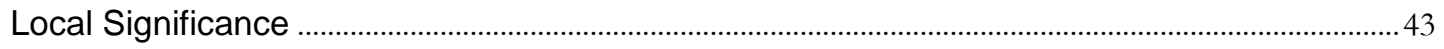

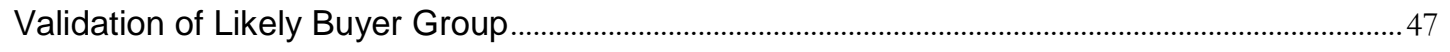

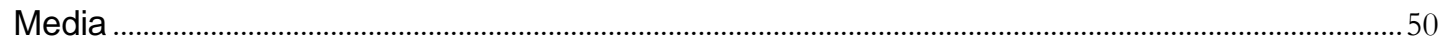

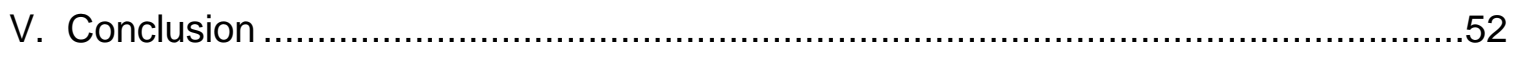

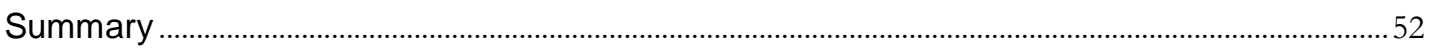

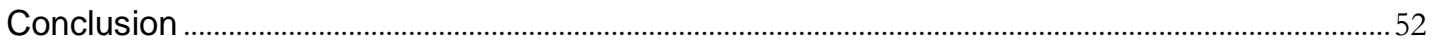

Discussion .......................................................................................................................................5 


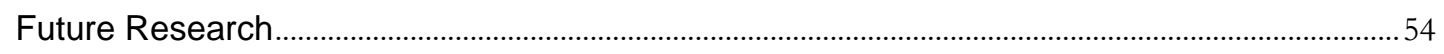

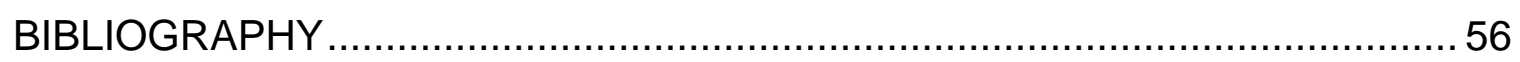

APPENDIX A

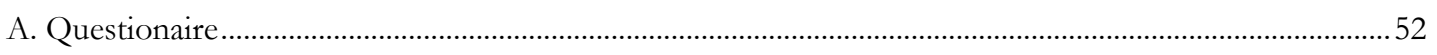




\section{LIST OF TABLES}

Table 1: Households in San Luis Obispo that consume meat products........................... 6

Table 2: Likelihood of Purchase for US Consumers, Red Meat, Fresh/Frozen. .............. 8

Table 3: Households in San Luis Obispo that consume meat products.......................... 9

Table 4: Attributes of beef that consumers are searching for....................................10

Table 5: 2010 US Census Populations for Specified Locations.....................................20

Table 6: Likely and Non-Likely Buyers of Cal Poly Meat Products...............................27

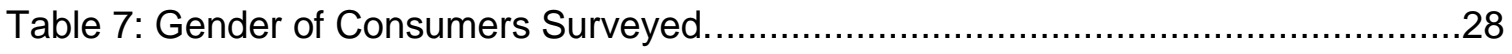

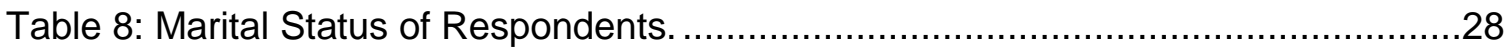

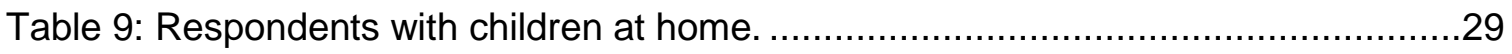

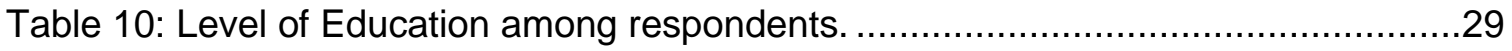

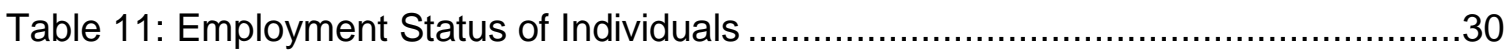

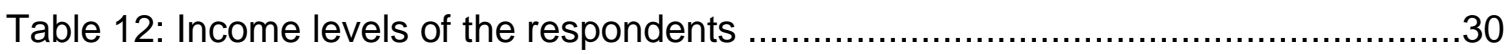

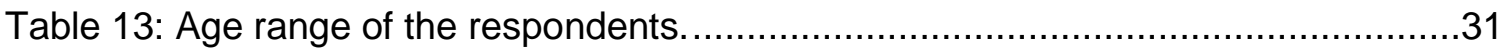

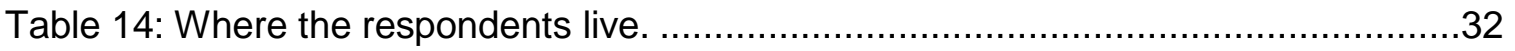

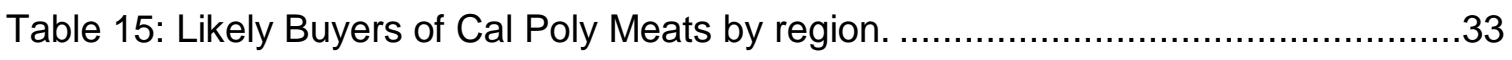

Table 16: Meat Purchasing Behavior..................................................................33

Table 17: Cal Poly food and wine products purchased by respondents. .......................34

Table 18: Cal Poly's food and wine products quality rating by respondents..................34

Table 19: Cal Poly's food and wine products convenience to purchase rating by

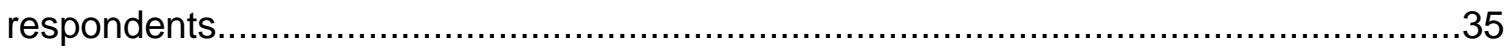

Table 20: Cal Poly's food and wine products value for the money evaluation by

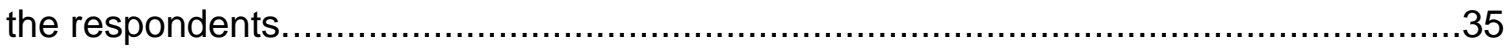

Table 21: Locations of meat purchases in San Luis Obispo County. ............................36

Table 22: Approximate amount of money spent on meat products in a typical month by likely buyers and non-likely buyers groups..............................................37

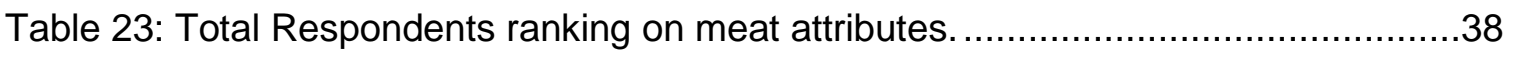

Table 24: Difference between groups' value in meat attributes....................................39

Table 25: Attributes importance within the likely buyer group. ………..........................39

Table 26: Respondents price reaction to concept board. ...........................................42

Table 27: Respondents involvement in local food initiatives. ....................................42

Table 28: Likelihood of traveling to campus to purchase meat, if free parking was

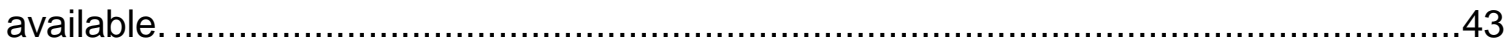

Table 29: Defining local in the sense of miles from home.......................................43

Table 30: Defining local in the sense of regions from home.......................................44

Table 31: Representation of mileage or regions importance over the other. ..................44

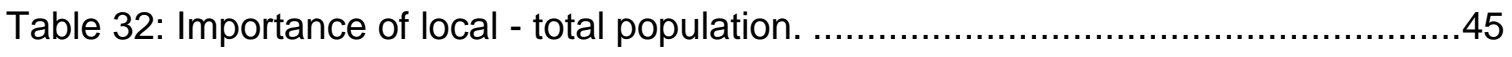

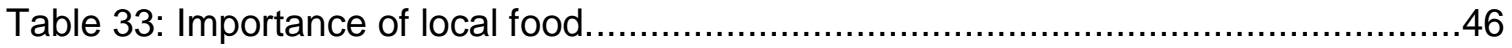

Table 34: Likely buyers' importance of local products...............................................46

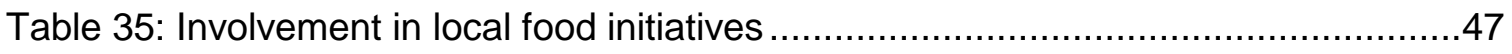

Table 36: Likelihood of likely Cal Poly meat buyers at a Farmers' Market.....................47

Table 37: Likely, Prospect, and Non-Likely Buyers of Cal Poly Meats. .........................48 
Table 38: Likely, Prospect, and Non-likely Buyers purchasing Cal Poly Meats on

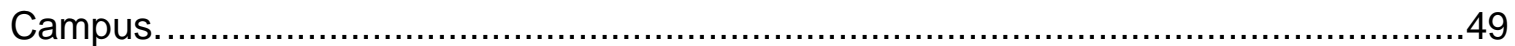

Table 39: Likely, Prospect, and Non-likely Buyers at farmers markets.........................49

Table 40: Likely, Prospect, and Non-likely Buyers price impression on Cal Poly Meat Products.

Table 41: Media channels that are recognized meat purchasers. 


\section{LIST OF FIGURES}

Figure 1: J\&G Lau Family Meat Processing Center. 5

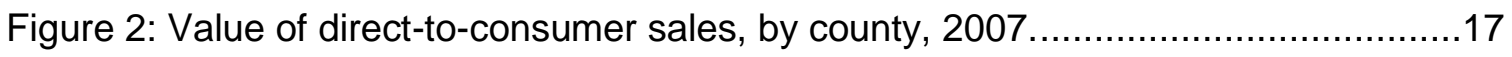

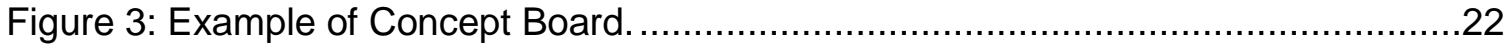

Figure 4: Example of Concept board. .................................................................... 41 


\section{Chapter I}

Introduction

Food producers are marketing their products based on the attribute that it is produced locally. Many operating farmers' markets carry local foods and research has shown that consumers have positive perceptions of local foods. There are numerous definitions for defining 'local' concerning food production.

Having seen tremendous growth in marketing local products, California Polytechnic State University, San Luis Obispo (Cal Poly) is providing hands-on experience to their students by giving them the opportunity to market locally produced foods at a local farmers' markets.

\section{Motivation}

Research on the topic of local meat has been conducted from the middle part of the nation to the eastern side of the United States (US); however, little research has been specifically conducted on the West Coast meat market. A focus group in Kansas concluded the term local can be applied to meat products, but could not define what local meant (Harris et al., 2000). With little research on the local market and local demographics in relation to meat consumers on the Central Coast of California, research is needed to understand if local is an attribute that attracts meat consumers to purchase meat. This study conducts a consumer survey using a personal interview method to examine the desirability of local meat in the consumer's purchase decision.

The findings of this research will aid in advancing the Cal Poly San Luis Obispo meat department's effort to appropriately market its meat in the area. As part of this 
survey, an assessment of the appropriate channel of distribution for these meat products (Famers Markets, and Grocery Outlets) will be evaluated for proper sale of goods. The study will also provide profile of the target consumer.

Problem Statement

Cal Poly's "learn by doing" strategy provides students with the opportunity to produce their own meat products and market them to the local region. It will be beneficial for Cal Poly's needs to get a better understanding of the factors and attributes that motivate consumer to purchase meat and the Cal Poly brand. Local is one attribute Cal Poly can use to attract purchasers. This study will identify the target market and attributes that motivate meat purchasers. There are many definitions of local for use in marketing food products. With such variety of definitions being used within the food industry to define local, it is important for Cal Poly understand how its target market perceives local to be defined. The following hypothesis will be considered in this study.

Hypothesis

Hypothesis 1

$\mathrm{H}_{\mathrm{o}}=$ The likely buyer for local Cal Poly meat in San Luis Obispo County will be a heavier spender on meat and older.

$\mathrm{H}_{\mathrm{a}}=$ The likely buyer for local Cal Poly meat in San Luis Obispo County will not be a heavier spender on meat and older.

Hypothesis 2

$$
\begin{aligned}
& H_{0}=\text { The likely buyer for Cal Poly meat, believes local food to be important. } \\
& H_{a}=\text { The likely buyer for Cal Poly meat, does not believe local foods to be }
\end{aligned}
$$
important. 
Hypothesis 3

$\mathrm{H}_{\mathrm{o}}=$ Respondents will not define local as being in a set mileage radius from home, but rather in the vernacular sense by geographical boundaries.

$\mathrm{Ha}=$ Respondents will define local as being in a set mileage radius from home, and not in the vernacular sense by geographical boundaries.

Objectives

The objectives of this thesis are the following 1) to identify the target market consumer for local Cal Poly Meats; 2) to determine the importance of local food to consumers; 3 ) to determine what is commonly defined by meat consumers in San Luis Obispo as 'local' food. 


\section{Chapter II}

\section{Literature Review}

The literature review for this research survey examines several topics including meat consumers' perceptions of the definition of 'local' (mileage and geographical location). There is specific emphasis on meat consumers' demographics and behaviors, how consumers prefer to define as 'local', the importance and desirability associated with products that have the 'local' attribute and a profile of the primary purchasers of farmers' market products.

\section{Background}

The J \& G Lau Family Meat Processing Center (Figure 1) was built to access the products on-campus and market them to the community. The facility provides a key link in educating agricultural students in the entire process of raising livestock for food production. This study aims to provide Cal Poly's meat department and the Animal Science's livestock with information on how to best market their products to the local community. 


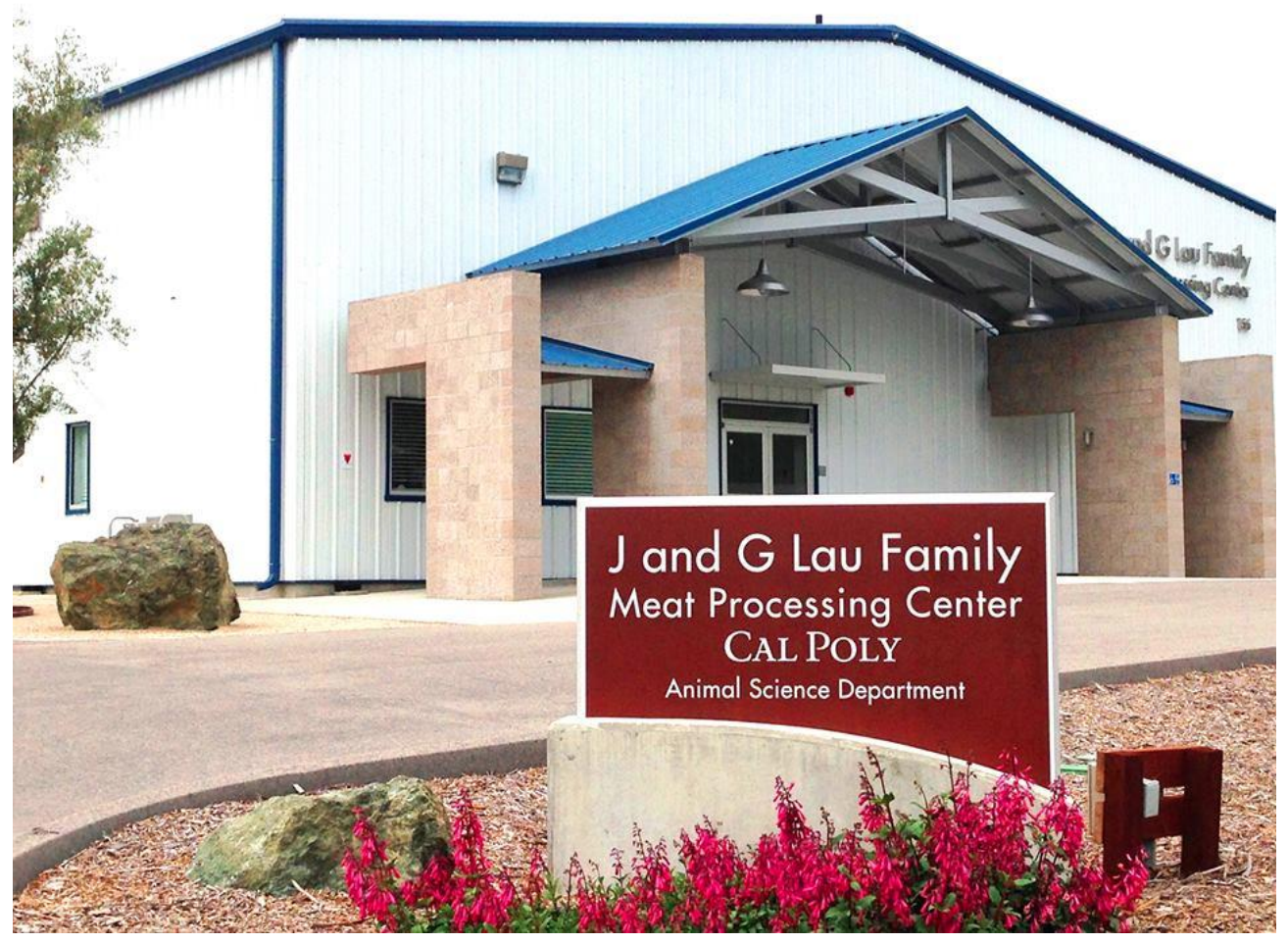

Figure 1: J\&G Lau Family Meat Processing Center.

\section{Meat Consumption}

In recent years, meat volume sales have decrease by 2 percent, but in the foreseeable future meat volume sales are projected to increase by about 4 percent in 2017 (Euromonitor, 2013). The decrease in meat consumption is due to a stiffer economy and increase in feed cost that are causing consumer to spend less on proteins. In 2013 , the total US fresh meat market dollar sales were $\$ 44.5$ billion dollars (Beefretail.org). With spending of $\$ 44.5$ in 2013 , per capita consumption in the US was found to be 203.2 lbs per person (Elem, 2014). Per capita consumption is higher than year prior but has remained lower that the 90's and 00's recorded consumption of meat products (Elem, 2014). 


\section{Meat Purchasers}

Below in Table 1, is the breakdown of the US principal meat shoppers and who is the most likely to purchase the meat products. The data is provided by GFK MRI+ reporter (2012) and is broken down into the 4 most popular red meat categories: chicken, lamb, pork and beef. Along with each of these categories, the data is then separated into demographic descriptors: sex, age, marital status, education, income, and region. These 6 descriptors will provide a snapshot in whom and what areas of the US are purchasing certain types of meats.

Table 1: Households in San Luis Obispo that consume meat products.

\begin{tabular}{|l|c|c|}
\hline \multicolumn{2}{|c|}{$\begin{array}{c}\text { Percentage of Household in } \\
\text { US that Consume Meat } \\
\text { Products* }\end{array}$} & $\begin{array}{c}\text { Households in San Luis } \\
\text { Obispo that Consumer } \\
\text { Meat Products** }\end{array}$ \\
\hline Chicken & $80.20 \%$ & 94,089 \\
\hline Pork Chops & $41.30 \%$ & 48,452 \\
\hline Beef & $5.40 \%$ & 82,592 \\
\hline Lamb & $70.40 \%$ & 82,592 \\
\hline
\end{tabular}

*Source: MRI Plus 2012 Consumer Data

**Source: US Census Data, San Luis Obispo County.

Total Households in San Luis Obispo County, 117,318.

The top section of the Table 1 shows total purchasers of meat products in the US for 2012 from GFK MRI + Reporter (MRI+, 2012). MRI found that the most popular consumed meat product in the US is chicken (80.2 percent). Additionally, the second most popular meat source was beef with 70.4 percent consumption rate, followed by pork at 41.3 percent, and lastly by lamb at 5.4 percent.

In the first column, chicken, is purchased primarily by females, 35-64 years of age and with the highest likelihood that she has some education after her college 
degree. Interestingly enough, the individuals that have graduated from at least high school have purchased chicken in the last 6 months. The largest proportion of chicken consumers has the yearly income range of $\$ 75,000$ to $\$ 149,000$ year, and those that are married.

More males purchase lamb than other meats. However, married female principal shoppers purchase lamb, with high levels of education and to be within the older, 55-64 years of age. The higher level of education is consistent with annual income found to making over $\$ 150,000$ a year. Lamb is shown to be very prevalent among shoppers in the northeast and to be popular among the western residents.

In the third column is pork. Pork is purchased more often by lower educated females, who are in the mid-to-older crowd (35+ years old). Income purchasers for pork products are likely to be making $\$ 30,000-\$ 39,000$ a year and live in the Midwest. Furthermore, purchasers of pork products are noticed to be married. The beef purchasers are presented to have graduated from high school with some college experience. They are primarily married or engaged females that have a household income of $\$ 40,000-\$ 49,000$ and $\$ 150,000$ a year. Midwestern's are expected to purchase more beef products and range in age from 35-64 years of age. Drawing from across the collection of red species, purchasers are married, older, and have a household income of $\$ 50,000$ or more a year. 
Table 2: Likelihood of Purchase for US Consumers, Red Meat, Fresh/Frozen.

\begin{tabular}{|c|c|c|c|c|c|}
\hline & & Chicken & Lamb & Pork & Beef \\
\hline \multicolumn{2}{|c|}{ Total Shoppers that Consume } & $80.2 \%$ & $5.4 \%$ & $41.3 \%$ & $70.4 \%$ \\
\hline \multicolumn{6}{|c|}{$\begin{array}{ll}\text { Percentage that Purchase } \\
\end{array}$} \\
\hline \multirow{2}{*}{ Sex } & Male & $29.5 \%$ & $32.4 \%$ & $28.2 \%$ & $29.4 \%$ \\
\hline & Female & $70.5 \%$ & $67.6 \%$ & $71.8 \%$ & $70.6 \%$ \\
\hline \multirow{6}{*}{ Education } & High School & $12.4 \%$ & $9.2 \%$ & $13.2 \%$ & $12.2 \%$ \\
\hline & High School Graduate & $29.9 \%$ & $23.4 \%$ & $33.2 \%$ & $30.7 \%$ \\
\hline & No college & $42.1 \%$ & $35.1 \%$ & $45.1 \%$ & $42.5 \%$ \\
\hline & Attended College & $18.6 \%$ & $13.8 \%$ & $19.5 \%$ & $19.1 \%$ \\
\hline & College Graduate Plus & $29.3 \%$ & $42.4 \%$ & $24.3 \%$ & $28.1 \%$ \\
\hline & Post Graduate & $10.9 \%$ & $17.1 \%$ & $8.7 \%$ & $10.5 \%$ \\
\hline \multirow{6}{*}{ Age } & $18-24$ & $7.3 \%$ & $5.1 \%$ & $6.3 \%$ & $7.2 \%$ \\
\hline & $25-34$ & $17.7 \%$ & $15.6 \%$ & $15.3 \%$ & $17.8 \%$ \\
\hline & $35-44$ & $18.8 \%$ & $16.9 \%$ & $18.0 \%$ & $18.3 \%$ \\
\hline & $45-54$ & $21.0 \%$ & $20.4 \%$ & $21.3 \%$ & $20.7 \%$ \\
\hline & $55-64$ & $17.6 \%$ & $22.6 \%$ & $19.6 \%$ & $18.1 \%$ \\
\hline & $65+$ & $17.6 \%$ & $19.4 \%$ & $19.5 \%$ & $17.8 \%$ \\
\hline \multirow{8}{*}{ Income } & $\mathrm{HHI}:<\$ 20,000$ & $17.0 \%$ & $15.2 \%$ & $18.0 \%$ & $16.7 \%$ \\
\hline & HHI: \$20,000-\$29,999 & $10.8 \%$ & $6.4 \%$ & $11.0 \%$ & $10.9 \%$ \\
\hline & HHI: \$30,000-\$39,999 & $9.8 \%$ & $7.1 \%$ & $11.2 \%$ & $10.2 \%$ \\
\hline & HHI: \$40,000-\$49,999 & $8.6 \%$ & $9.2 \%$ & $8.7 \%$ & $8.9 \%$ \\
\hline & HHI: \$50,000-\$59,999 & $7.9 \%$ & $9.1 \%$ & $8.2 \%$ & $7.6 \%$ \\
\hline & HHI: \$60,000-\$74,999 & $9.8 \%$ & $10.0 \%$ & $9.7 \%$ & $10.0 \%$ \\
\hline & HHI: \$75,000-\$149,999 & $26.7 \%$ & $30.9 \%$ & $25.0 \%$ & $26.2 \%$ \\
\hline & HHI: $\$ 150,000+$ & $9.4 \%$ & $12.2 \%$ & $8.3 \%$ & $9.4 \%$ \\
\hline \multirow{4}{*}{ Region } & Northeast & $18.3 \%$ & $27.9 \%$ & $18.5 \%$ & $17.4 \%$ \\
\hline & South & $37.8 \%$ & $33.3 \%$ & $39.5 \%$ & $37.7 \%$ \\
\hline & Midwest & $22.4 \%$ & $16.8 \%$ & $25.1 \%$ & $23.9 \%$ \\
\hline & West & $21.5 \%$ & $22.0 \%$ & $16.9 \%$ & $21.1 \%$ \\
\hline \multirow{4}{*}{ Marital } & Never Married & $22.6 \%$ & $21.8 \%$ & $19.4 \%$ & $21.8 \%$ \\
\hline & Engaged & $4.5 \%$ & $53.0 \%$ & $4.4 \%$ & $4.7 \%$ \\
\hline & Married & $52.9 \%$ & $3.2 \%$ & $55.1 \%$ & $53.6 \%$ \\
\hline & Separated & $24.4 \%$ & $25.2 \%$ & $25.6 \%$ & $24.6 \%$ \\
\hline \multirow{5}{*}{ Employment } & Professional Occupation & $13.8 \%$ & $15.6 \%$ & $11.6 \%$ & $13.5 \%$ \\
\hline & Business \& Financial & $9.0 \%$ & $13.4 \%$ & $8.0 \%$ & $9.0 \%$ \\
\hline & Sales \& Office & $14.5 \%$ & $12.7 \%$ & $14.2 \%$ & $14.2 \%$ \\
\hline & Maintainer Occupations & $3.2 \%$ & $2.7 \%$ & $3.0 \%$ & $3.1 \%$ \\
\hline & Other Employed & $15.7 \%$ & $12.5 \%$ & $15.6 \%$ & $16.1 \%$ \\
\hline
\end{tabular}

Source: GFK MRI + Reporter

Index: Signifies the percentage that is likely to purchase that product.

Chicken: Used in the last 6 months Chicken (Principal Shopper)

Lamb: Used in the last 6 months Lamb (Principal Shopper)

Pork: Used in the Last 6 months Pork (Chops)(Principal Shopper)

Beef: Used in the last 6 months Beef (Principal Shopper) 
Meat Purchasers in San Luis Obispo

In 2000, a study was conducted in San Luis Obispo on a new branded beef product. The researchers aimed to determine what attributes the consumer's desire when they purchase meat through the use of simulated test marketing (concept board) to examine consumer acceptance of a Cal Poly Branded beef product. The study concept board displayed the words "- P Beef Cal Poly" with a picture of a New York Steak (Wolf \& Thulin, 2000b).

Table 3: Households in San Luis Obispo that consume meat products.

\begin{tabular}{|l|c|c|}
\hline \multicolumn{2}{|c|}{$\begin{array}{c}\text { Percentage of Household in } \\
\text { US that Consume Meat } \\
\text { Products* }\end{array}$} & $\begin{array}{c}\text { Households in San } \\
\text { Luis Obispo that } \\
\text { Consumer Meat } \\
\text { Products** }\end{array}$ \\
\hline Chicken & $80.20 \%$ & 94,089 \\
\hline Pork Chops & $41.30 \%$ & 48,452 \\
\hline Beef & $5.40 \%$ & 82,592 \\
\hline Lamb & $70.40 \%$ & 82,592 \\
\hline
\end{tabular}

*Source: MRI Plus 2012 Consumer Data

**Source: US Census Data, San Luis Obispo County.

Total Households in San Luis Obispo County, 117,318.

On the concept board, zero mention of any attribute was lost nor was price. The researchers found that 35 percent of the respondents in the survey were 90 percent in a 100 percent to purchase the new branded beef in the stores (Wolf \& Thulin, 2000a). Of the total population that responded to the survey the researchers found that "Reasonably Priced," "Good Value for Their Money" and "High Quality Grade" were the highest ranked attributes desired by consumers of beef (Wolf \& Thulin, 2000a). In the list of attributes that the consumers rated, no mention of how the consumer responded to a local brand terminology was cited by the researchers. It suggests that consumers' preference in food can change over time. 
The researchers also determined that the target consumers were female, married and are from a dual-income household (Wolf \& Thulin, 2000a). Additionally, the consumer was 40-50 years of age and had a higher education (Wolf \& Thulin, 2000a). These results are very specific to the region of San Luis Obispo, and do not give an accurate description of what the national consumer looks like. However, they are useful for the purposes of this research because this research is based in San Luis Obispo.

Table 4: Attributes of beef that consumers are searching for.

\begin{tabular}{|l|c|c|}
\hline & $\begin{array}{c}\text { Mean } \\
(\mathrm{N}=405)\end{array}$ & $\begin{array}{c}\text { Standard } \\
\text { Error } \\
(\mathrm{N}=405)\end{array}$ \\
\hline \multicolumn{2}{|l|}{ Very to Extremely Desirable } \\
\hline Reasonably Priced & 4.38 & 0.04 \\
\hline Good Value For the Money & 4.34 & 0.05 \\
\hline High-Quality Grade & 4.24 & 0.05 \\
\hline Is Lean & 4.17 & 0.05 \\
\hline Color & 4.14 & 0.05 \\
\hline Healthy & 4.01 & 0.06 \\
\hline Somewhat to Very Desirable & 3.72 & 0.06 \\
\hline Juicy & 3.63 & 0.05 \\
\hline Premium Brand & 3.54 & 0.06 \\
\hline Quick Preparation Time & 3.29 & 0.08 \\
\hline Boneless & 3.21 & 0.06 \\
\hline Natural & 3.19 & 0.07 \\
\hline Easy-to-Clean-up & 2.73 & 0.07 \\
\hline Slightly To Somewhat Desirable & 0.07 \\
\hline Family Pack & 2.57 & 0.07 \\
\hline Single Serving & 2.22 & 0.09 \\
\hline Grass-Fed & 2.39 \\
\hline Certified Organic & 3.5 \\
\hline
\end{tabular}

(5- Extremely Desirable, 4- Very Desirable, 3- Somewhat Desirable, 2Not Very Desirable, 1- Not Desirable at All) 


\section{Defining Local}

The definition of local varies from study to study; one study indicates that the purpose of buying 'local' is to cut down on the average 1,500 miles that food travels to make it to the plate (Burros, 2007, Voight, 2012). Local food demands by consumers have grown and gained enormous popularity over the years, but the precise meaning of how 'local' is defined geographically is unknown. Some scholars determine that local products, more specifically meat products, are raised within a 100 mile radius from the home. Others, however, suggest that local can be defined within a county, region or state in which that consumer lives. There are also studies that combine the two and determine that they share a part of the definition.

Food, Conservation, and Energy Act of 2008 defines local as a product that is transported less than 400 miles (Martinez et. al, 2010). This definition derived by the Act and by the US government, does not agree with research conducted by the academic world. Focus groups in Wisconsin and Kentucky went through discussions on defining local, but neither group could give a clear-cut definition (Harris et. al., 2000: Zepeda \& Leviten-Reid, 2004). Nevertheless, one group was able to conclude that the term local could be applied to both meat and dairy products (Harris et. al., 2000).

Looking solely at the mileage radius definition for 'local', it is evident that the research is not consistent. A study in the Midwest found 'local' to be defined as grown less than 25 miles from their home (Porig, 2004). This definition conflicts with another study that found local to be less than 100 miles from the home (Adams \& Adams, 2011). On the national level, respondents stated less than 100 miles was considered to be local, followed by within their state (Hartman, 2008). These findings indicate that the term local has different meanings for different consumers. 
Another measuring tool for determining 'local' is in a geographical sense. Rather than looking at the idea of a radius, some people perceive distance differently. This could be due to physical boundaries, which may impact the perception of 'local.'

Research in the northwest found that 'local' varied between three counties directly next to each other (Selfa \& Qazi, 2005). When asked to define local, the most popular answer between two counties stated that products grown within their counties and neighboring counties (Selfa \& Qazi, 2005). Even more interesting, is the third county surveyed in Washington stated that local meant grown within Washington State or the northwest region (Selfa \& Qazi, 2005). A similar study found that consumers considered the state boundary to be the definition of 'local' (Onken, Bernard \& Pesek, 2011; Wilkins, Sobel, \& Bowdish,1996). In larger states it might be a region that is considered 'local' (Martinez et. al., 2010). The research does suggest the possibility that state size indeed does matter in determining what boundaries are considered to be 'local'.

An Ohio study showed that the respondents did not see a difference between 'produced nearby' and 'produced in Ohio,' and suggested the state to be the boundary for the 'local' definition (Darby et. al., 2008). A significant limitation to the study conducted in Ohio is what the consumer considers to be nearby. While the study showed to have significant results, the definition of nearby 1) differs from individual to individual and 2) in no way can "Produced in Ohio" be graphically represented to be the same as nearby.

Value of Local

When consumers are deciding on what to purchase, attributes about the products play a very significant role in determining the purchasing of products. Ultimately the term local and how the consumer may define it, carries a value with it. This value 
carried with the term was found in several studies about willingness to purchase. Whole Foods, a giant in the local and organic produce foods, sees the growth in the local product field. 47 percent of adults that participated in a survey issued by whole foods stated that they would be "willing to pay more for fruit, vegetables, meat and cheese produced near their homes" (Satran, 2012).

Survey respondents noted that "locally produced" was important in their choice of purchasing beef in one study (Franken, Parcell, \& Tonsor, 2011). Similar to those findings, another group found that consumers are willing to pay more for a locally produced, natural beef (Grannis \& Thimany, 2000).

Toler et al. concluded that people preferred buying from local farmers rather than non-local farmers with identical products (2009). The author then suggested consumers preferred local because they sold their farmers that markets their products in a direct to consumer fashion. Other research concluded consumers' willingness to pay a premium for a local product ranges from 10-28 percent (Thilmany et al., 2008; Umberger et. al., 2009). Confirming these results, a South Carolina study found that the consumers were willing to pay a premium of 23 percent for animal products that were produced in the state (Caprio, 2008). Hu et.al. (2012) found that when the consumer was knowledgeable of where the product was produced in the state, the consumer had a WTP premium of 31 cents. The study used a conjoint analysis that denoted several attributes for a product at one time, brand, region of production, ingredients, price and made with what type of fruit.

Conventional Vs. Organic

In a review of literature completed in 2012 , authors found that information regarding organic food compared to conventional foods. The ultimate finding of the 
review was that organic foods lack strong evidence that they are robustly better than conventional foods (Smith-Spangler, 2012). However, the authors did mention that for the numerous reasons that the consumers do purchase organic foods, the most popular reason to steer away form antibiotic-resistant bacteria and pesticide residues.

\section{Farmer's Markets}

Farmers' markets are established on the idea of direct-to-consumer marketing in which farmers are bypassing the "middleman" (distributors and grocery stores) and selling their products directly to the consumer. During the 2007 United States Census of Agriculture (USCA), the direct-to-consumers segment of the agricultural industry totaled $\$ 1.2$ billion dollars (Martinez et.al., 2010).

The United States Department of Agriculture (USDA) Economic Research Service (ERS) uses the term 'quadrupled' to describe the total number of farmers' markets that have registered with the USDA National Farmers' Market Directory (USDANFMD) from 1994 and lasting through 2012 (USDA-ERS, 2013). When the USDANFMD was initiated in 1994, a total of 1,755 farmers' markets were voluntarily registered. In 2013, the USDANFMD grew a total of 8,144 registered markets (USDAERS, 2013). Even more impressive is the fact that between 2012 and 2013, farmers' markets registered with the USDA increased 3.6 percent (USDA-ERS, 2013).

Currently there are over 700 certified farmers' markets registered in California (CDFA, 2014) and this is the most of any state (USDA-AMS, 2012). The ability of California to host the most farmers' markets is, in part, attributed to its capacity to grow many agricultural products in the states. In 2012, California was ranked as the number 1 state in the nation in terms of cash receipts (CDFA, 2014). A large advantage that California possesses in hosting farmers' markets year-round is its ability to stay 
climatically consistent more so than other states and regions. With approximately 700 certified markets, over 51 percent of them are year-round with the remainder being seasonal (CDFA, 2014). Year-round farmers' markets provide access to customers that are willing to pay a premium for having a fresh and locally sourced product nearby (Hardesty, 2008). A year-round farmers' market provides a facility for farmers to market and sell their product throughout the year and generates steady cash flow for their operation.

Products sold at a farmers' market include fresh fruits, vegetables, cut flowers and meat products. Between 2002 and 2007 the increase in beef products and other meat products rose 33 percent and 6 percent respectively (Martinez et.al., 2010). The 2007 USCA determined there were 138,000 farms acknowledged their participation in direct-sales; of the 138,000 farms, 51 percent were livestock producers (Martinez et.al., 2010). Additionally, the 51 percent of livestock producers that took part, contributed roughly $\$ 372$ million to the direct-sales total (Martinez et.al., 2010). Part of the draw that pulls consumers into direct-sales is the quality and freshness that is associated. Many studies have shown that direct-sales offer higher quality products in their local area (Wolf, Spittler, \& Ahern, 2005).

\section{Farmers' Market Consumers}

Previous research has found the decision to purchase local food at farmers' markets is based on a variety of attributes of the consumer. Attributes include, but are not limited to: race, age, marital status, income, employment status and education. The most applicable research that can be applied was conducted in 2005 at California, San Luis Obispo (SLO) County farmers' markets. Researchers concluded the demographic profile tended to be older, married individuals with full time-employment (Wolf, Spittler, \& 
Ahern, 2005). They also found the shoppers were in the middle to higher end of the income scale $(\$ 40,000+$ in yearly income $)$, completed post-graduate work and were willing to travel to famers' markets to purchase local produce directly from the farmers (Wolf, Spittler, \& Ahern, 2005). These findings confirmed the results of a study conducted years earlier in Northern and Central New Jersey (Govindasamy, Italia, \& Adelaja, 2002). The New Jersey study concluded that females with an average age of 51 years old, who had graduated from college and had high levels of income to be the primary farmers' market participants (Govindasamy, Italia, \& Adelaja, 2002). Interestingly enough, the two studies, while on different sides of the US showed the same results in demographics.

A study in Alabama concluded that as the age of the consumer in the farmer-toconsumer sale increased, the consumer was more likely to purchase directly from a farmer (Onianwa, Wheeloack, \& Mojica, 2005). The results showed a positive correlation (Onianwa, Wheeloack, \& Mojica, 2005). Additionally, families with children in the study were found to be shopping at a direct-to-consumer outlet, when income increased (Onianwa, Wheeloack, \& Mojica, 2005). The study concluded that families are concerned with where their food products are produced.

Alternatively, a study conducted in Missouri found that the age, income or level of education did not play a significant role in purchasers buying local produce (Brown, 2003). However, the author did conclude that farm connection had an influence on the purchasing of local products (Brown, 2003).

Reasons to Purchase at Farmers' Markets

Consumers all over the nation are fueling the increase of farmers' markets as they search for locally produced products. In 2007, the USCA determined the 
West Coast had the highest-valued counties in terms of total amount of sales. Figure 1 is a map of the US that is broken into counties and shows the amount of sales per county.

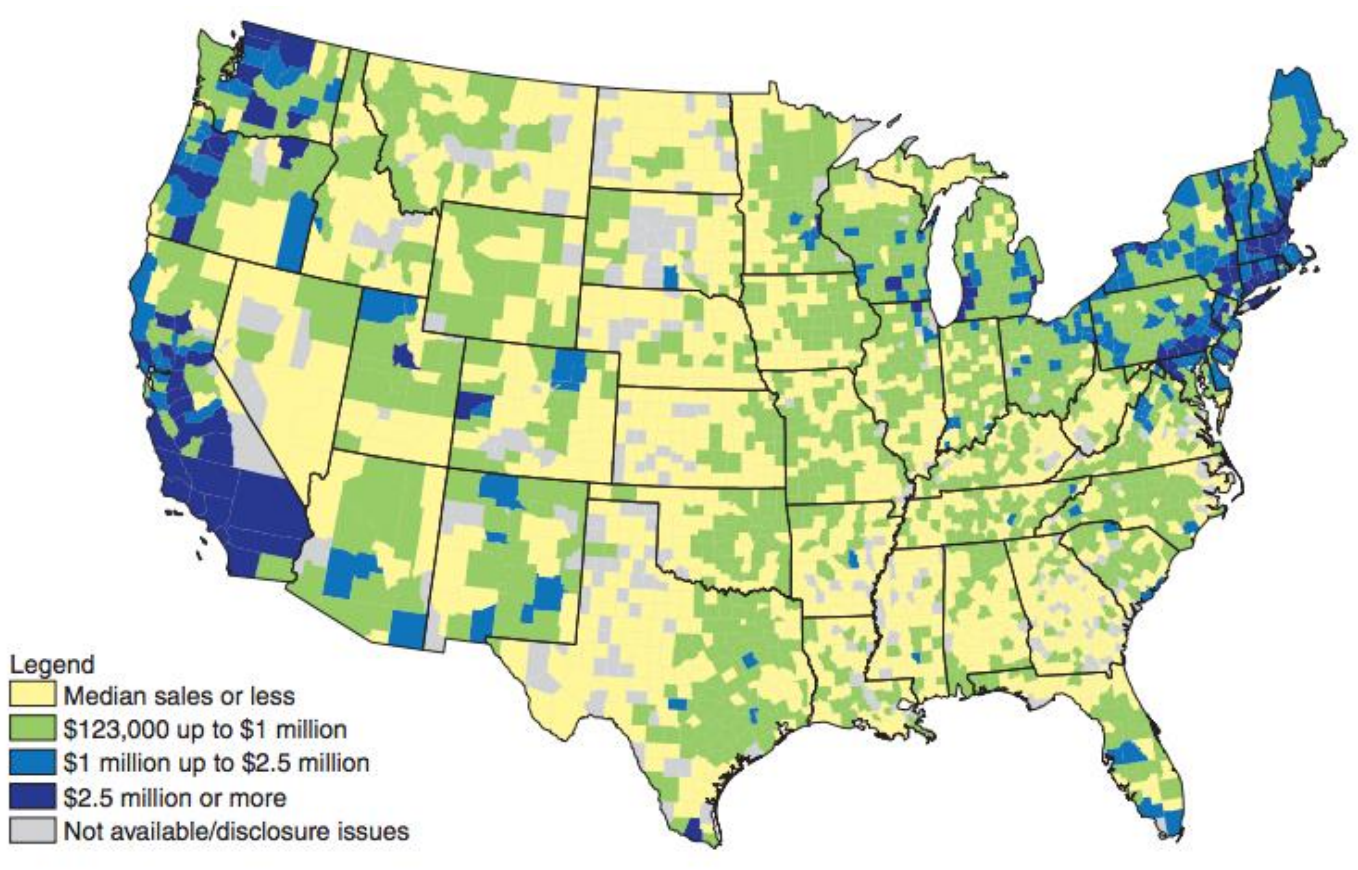

Source: USDA, National Agricultural Statistics Service; 2007 Census of Agriculture.

Figure 2: Value of direct-to-consumer sales, by county, 2007.

The most significant purpose for consumers to be purchasing at a direct-toconsumer outlet, such as farmers' market, is for higher quality foods. A 2001 study in Oklahoma found quality to be the most import factor for purchasing at the farmers' markets (Kerr, 2001). Following quality, respondents stated that supporting local business and buying products of the state to be other important factors in shopping at the farmers' markets (Kerr, 2001). Similar to these findings, 90 percent of the patrons in New Jersey said the main reason for visiting farmers' markets was due to the freshness of the products and the direct contact with the farmers (Govindasamy, Italia, \& Adelaja, 2002). 
In California, attributes of the products sold at farmers' markets have the same draw as elsewhere in the US. In the San Luis Obispo farmers' market, the main reason for residents to attend was to purchase high quality products and produce (Wolf, Spittler, \& Ahern, 2005). Attendants of the San Luis Obispo farmers' markets ranked the produce sold to be 'fresh looking, fresh tasting, and a high quality product (Wolf, Spittler, \& Ahern, 2005).' Additionally, these resident shoppers stated another reason to attend was to buy directly from the farmers (Wolf, Spittler, \& Ahern, 2005). 


\section{Chapter III}

\section{Methodology}

\section{Procedures for Data Collection}

Data for the research project was collected using a consumer based survey that was conducted using the personal interview method outside supermarkets and farmers' markets throughout San Luis Obispo County in February, March, and April of 2014. Surveys were conducted in individual cities of the county based on the proportion of the population in the county.

2010 U.S. Census (data) was used to determine the cities' population composition and appropriate percent of surveys. Table 1 below, shows the city breakdown and percentage of respondents for the sample size. Within each city, surveys were collected at farmers' markets and in front of supermarket/grocery stores. The goal of collecting in both of these locations was to create an unbiased collection of surveys that gather from the representative meat purchaser in San Luis Obispo County. This includes consumers that do not purposefully purchase local meat and those that do purposefully purchase local meat. 
Table 5: 2010 US Census Populations for Specified Locations.

\begin{tabular}{|l|c|c|c|c|}
\hline & Population & $\begin{array}{c}\text { Non- } \\
\text { Likely } \\
\text { Buyers } \\
(\mathrm{N}=199)\end{array}$ & $\begin{array}{c}\text { Total } \\
(\mathrm{N}=290)\end{array}$ & $\begin{array}{c}\text { Chi- } \\
\text { Square }\end{array}$ \\
\hline San Luis Obispo & 45,119 & $29 \%$ & 95 & $32 \%$ \\
\hline Pismo Beach & 7,655 & $5 \%$ & 9 & $3 \%$ \\
\hline Arroyo Grande & 17,252 & $11 \%$ & 30 & $10 \%$ \\
\hline Morro Bay & 10,234 & $7 \%$ & 43 & $15 \%$ \\
\hline Grover Beach & 17,252 & $11 \%$ & 30 & $10 \%$ \\
\hline Atascadero & 28,814 & $18 \%$ & 10 & $3 \%$ \\
\hline Paso Robles & 30,556 & $19 \%$ & 30 & $10 \%$ \\
\hline Other & - & $0 \%$ & 41 & $14 \%$ \\
\hline Total Population & 15,6882 & $100.0 \%$ & 295 & $100.0 \%$ \\
\hline
\end{tabular}

*Numbers gathered from 2010 Census Data

The survey is presented in Appendix A. The questionnaire contains 26 questions, including 8 questions on personal description characteristics, 8 questions on general purchasing habits, 5 questions on the 'local' attribute and definition of local, and 5 questions on meat purchasing habits.

Respondents were asked if they would like to answer a survey concerning a consumer based study on local meats. If the respondent said they were willing to take the survey, the interviewer then read the Informed Consent that had been approved by the Human Research Committee. Following reading of the informed consent, the interviewer read aloud the rest of the survey to the potential respondents.

Questions 1 \& 2 were elimination questions, where the respondents were asked, if they consumed meat in the last year and if they were older than 18 years of age, respectively. If the respondent stated that they did not eat meat they were thanked for their time and dismissed. If the respondent answered that they were younger than 18 years of age, they were thanked for their time and dismissed. Questions 2 \& 3 asked 
about Cal Poly branded food and wine products in relation to consumption and attributes of the products, respectively. Questions $4-9$, asked about the respondents purchasing habits and inquired about the attributes of the meat products that they purchase.

Questions 10-14 are designed to collect respondents definitions and perceptions of the product attributes 'local' and rate how important when purchasing various products (fruits, produce, meats and wines). An example of this is question 11 that asked: "When thinking about purchasing local food products, how do you define local?" Possible answers to the question included the following: $<10$ miles from home, $<30$ miles from home, $<50$ miles from home (Khan \& Prior, 2010), $<100$ miles from home, 100+ miles from home, and I Don't Know. 


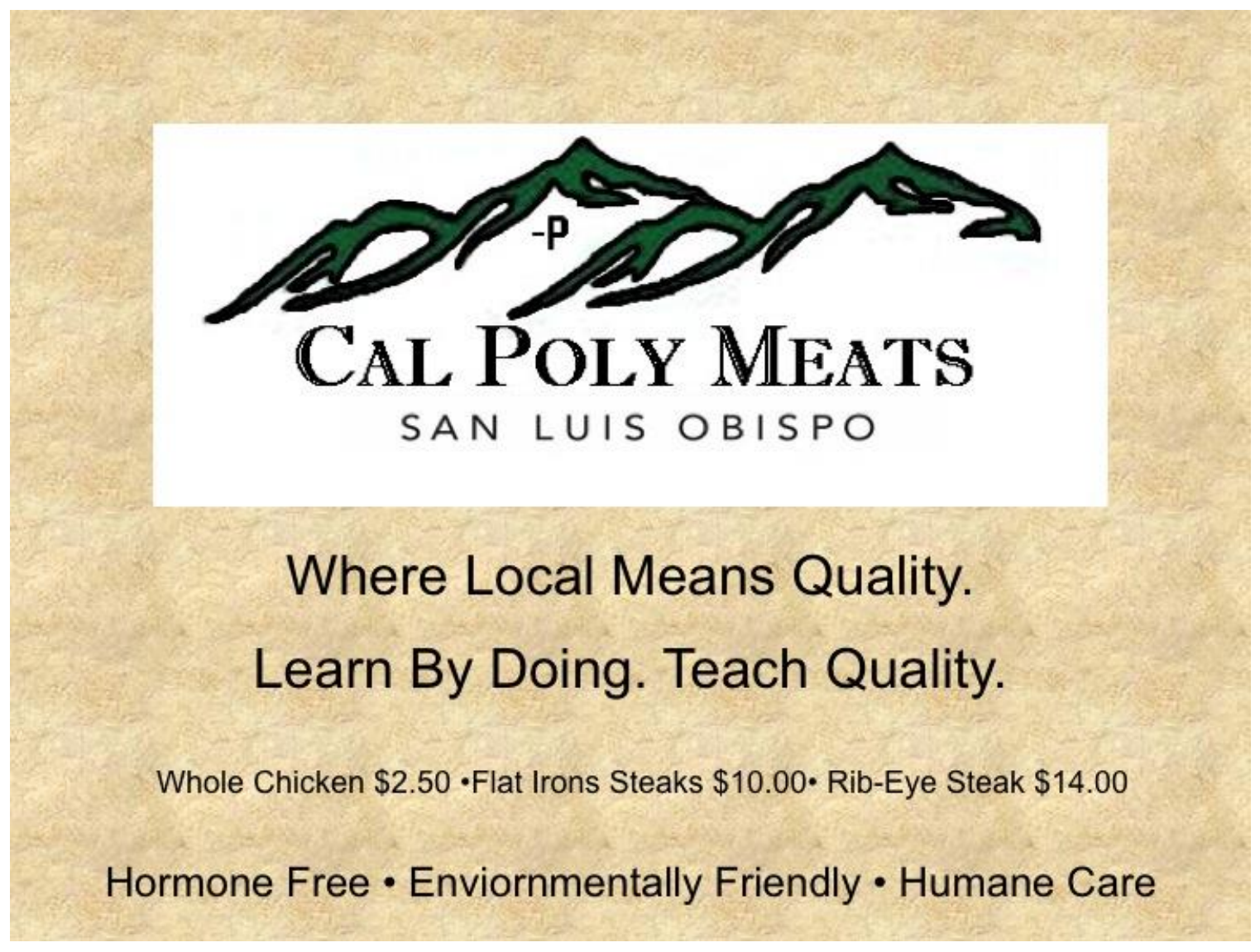

Figure 3: Example of Concept Board.

To understand consumer's interest in purchasing Cal Poly Meats, product simulated test marketing was developed and implemented. Simulated test marketing is designed to gain information and experience with a marketing program and to predict outcomes of a product's marketing plan in its designated area (Clancy, Kreig, and Wolf, pg 22). The test can use many different ways to measure and determine the market viability for a product. Through the use of market awareness, concept boards, likelihood to purchase and positioning research, the researcher can gain valuable information on the consumer in the region. 
Through the use of a concept board, Figure 2, and a follow up question, it was determined what percentage of customers in the given area was willing to purchase our product. The follow up was question was designed based on the Juster Scale (Morrison, 1979). The Juster Scale has been found to be a more accurate predictor of consumers purchasing intentions than other buyer intentions scales (Day et. al., 1991). The scale is broken down into 11 interval categories, on a willingness to complete a single purchase in the next year (Morrison, 1979). Categories range from 0 to 100 (in increments of 10) with an answer of zero being the lowest with "No Chance Will Buy" and 99 being the highest possible answer with 'Certain Will Buy.' A time frame element is added into the question, which can range from 3 to 24 months with accurate results (Day et. al., 1991). For the study a time frame of one year to purchase was set as the time frame.

\section{Procedures for Data Analysis}

The data was analyzed using SPSS Software. The target consumers were identified as those with a 90 percent or higher likelihood to purchase Cal Poly meats if it were available in a store where they shop in the next twelve months. Through the use of statistical analyses, a demographic profile of the target shopper was generated along with their purchasing habits, categorical behavior, and most effective media sources for the target consumer. The questions in the survey consist of nominal, ordinal, and ratio data. Statistical tests consisted of frequencies, Chi-square tests, t-tests and paired sample t-tests.

A Chi-square test is used to determine the numerical value two pieces of data share. More commonly, Chi-square test is used to determine averages of a specific 
data set. An example of a Chi-square test is when a research looks at how much a specific age group of individuals spends a month, week or day on food products.

A t-test is completed when determining the relationship of two categories or pieces of information has. This test is not done with have averages or quantitative data, but more so with qualitative data. An example of a t-test is the relationship between our likely buyers and their gender.

A paired sample t-test is similar to a t-test but looks at the quantitative data more closely. Similar to the t-test, averages are not able to be determined with a paired sample t-test, but more so to determine the relationships within a category of data. An example of a paired sample t-test is when suspected hierarchy is present in a category of product attributes. The paired sample t-test is used to determine the relationship between two attributes.

Nominal data is a category of data that does not fit into any type of natural order (Abramson \& Abramson, 2008). Common examples of nominal data are marital status, employment status, or location of home. A number is assigned to the categorical data, but does not refer to the rank. Analysis of this type of data is completed through a Chi-square test.

Ordinal data fall into categories that have a natural order or rank (Abramson \& Abramson, 2008). Ordinal data is commonly seen within questions that consist of income per year and level of education. Ordinal data is also used in the Likerttype scale, where the responses are specific to a number (Abramson \& Abramson, 2008). Examples of an ordinal data set with the Likert-type scale would be, "How important is it to you to purchase Local Meats? Extremely Important - 5, Very Important 
- 4, Somewhat Important - 3, Not Very Important - 2, Not Important at all - 1." Analysis of these questions can be done through Chi-Square and a pair sample t-test.

Ratio data are responses that are in a numerical format where they can be continuous or discrete and have a true zero that can be reached (Abramson \& Abramson, 2008). An example would be, "On average how much money do you spend in a typical month on meat products?" To analyze ratio data, a t-test is used to find a mean and standard deviation of the responses, along with the $p$-value.

In order to determine the target consumer, the respondents were asked to look at Figure 2 and respond to question 14. If the respondents answered with an "Almost Sure Will Buy" (90 chances or higher), they were placed into the target group. If the respondent answered with a "Very Probable Will Buy" (80 chances in a hundred) or lower, they are considered to be part of the non-target group. Following selection of the target and non-target groups, a new variable was created to represent the two groups, 'Target' and 'Non-target'. The newly coded groups were then analyzed against the rest of the surveys collected to determine significant information.

A significant level of .05 and .10 was used to find significant relations between the target group and their demographic profile, purchasing habits, categorical behavior, and most effective media sources to reach. If a p-value higher than .10 was calculated, the corresponding null hypothesis was accepted, indicating that there was no relationship. If a p-value of less than or equal to 10 was calculated then the corresponding alternative hypothesis was accepted and the corresponding null hypothesis was rejected.

Results from the study are displayed in tables for easy understanding. The data from the study are used to determine the target market for local meat 
producers. In addition, media sources that are the best way to reach the target consumer are identified.

Assumptions

It is assumed the respondents are answering honestly and wholeheartedly to the questions that are being asked. Also, research done in the field on locally produced product is applicable to meat purchasers in San Luis Obispo County.

Limitations

Limitations to this study are as follows:

1) The study is limited to people that eat meat products

2) The study is limited to individuals that are older than 18 years of age

3) The study is in San Luis Obispo County and not an accurate representation of neither California nor the United States 


\section{Chapter IV}

Results

Likely and Non-Likely Buyers

The likely buyer group of consumers was based on answering question 14 (Appendix A) with an "Almost Sure Will Buy" 90 percent or higher answer. A non-likely buyer group was assembled based on answering question 14 with a "Very Probable Will Buy" 80 percent or lower answer. The target group consisted of 91 individuals or 31.4 percent of the respondents of the survey. The non-target group totaled 199 individuals and total 68.6 percent of the survey responses. Table 6 shows the breakdown of the two groups.

Table 6: Likely and Non-Likely Buyers of Cal Poly Meat Products.

\begin{tabular}{|c|c|c|c|}
\hline $\begin{array}{c}\text { How likely would you be to purchase in the next } \\
\text { year? }\end{array}$ & $\mathrm{N}$ & Percent & Grouping \\
\hline Certain Will Buy (99 chances in 100) & 40 & $13.8 \%$ & \multirow{2}{*}{$\begin{array}{l}\text { Likely Buyers } \\
\qquad(\mathrm{N}=91)\end{array}$} \\
\hline Almost Sure Will Buy (90 chances in 100) & 51 & $17.6 \%$ & \\
\hline Very Probable Will Buy (80 chances in 100) & 55 & $19.0 \%$ & \multirow{9}{*}{$\begin{array}{c}\text { Non-likely } \\
\text { Buyers ( } N=199)\end{array}$} \\
\hline Probable Will Buy (70 chances in 100) & 40 & $13.8 \%$ & \\
\hline Good Probably Will Buy (60 chances in 100) & 30 & $10.7 \%$ & \\
\hline Fairly Good Possibility Will Buy (50 chances in 100) & 26 & $9.0 \%$ & \\
\hline Fair Possibility Will Buy (40 chances in 100) & 15 & $5.2 \%$ & \\
\hline Some Possibility Will Buy (30 chances in 100) & 16 & $5.5 \%$ & \\
\hline Slight Possibility Will Buy (20 chances in 100) & 7 & $2.4 \%$ & \\
\hline Very Slight Possibility Will Buy (10 chances in 100) & 6 & $2.1 \%$ & \\
\hline No Chance You Will Buy (0 chances in 100) & 3 & $1.0 \%$ & \\
\hline
\end{tabular}


Consumer Demographics

The Cal Poly meat products were appealing to both males and females. Slightly more than half ( 54.4 percent) of the respondents were females. This percentage is a little higher than the typical US meat purchaser as shown in the national statistics from MRI data where the majority of purchases was females seen in Table 1.

Table 7: Gender of Consumers Surveyed.

\begin{tabular}{|c|l|c|c|c|c|}
\hline \multicolumn{2}{|l|}{} & $\begin{array}{c}\text { Likely Buyers } \\
(\mathrm{N}=91)\end{array}$ & $\begin{array}{c}\text { Non-Likely } \\
\text { Buyers (N=199) }\end{array}$ & $\begin{array}{c}\text { Total } \\
(\mathrm{N}=290)\end{array}$ & Chi-Square \\
\hline \multirow{2}{*}{$\begin{array}{c}\text { Are } \\
\text { you...? }\end{array}$} & Female & $54.4 \%$ & $49.0 \%$ & $50.7 \%$ & .391 \\
\cline { 2 - 5 } & Male & $45.6 \%$ & $51.0 \%$ & $49.3 \%$ & \\
\hline
\end{tabular}

Additionally, results show marital status and presence of children in the household do not have an impact on the likelihood to purchase Cal Poly meats. The highest percentages of meat consumers were married followed by single as seen in Table 8. In Table 9, the total population is not likely to have children under the age of 18 at home. This sample is similar to the national meat consumption data from MRI in Table 1.

Table 8: Marital Status of Respondents.

\begin{tabular}{|l|l|c|c|c|c|}
\hline \multicolumn{2}{|c|}{} & $\begin{array}{c}\text { Likely } \\
\text { Buyers } \\
(\mathrm{N}=91)\end{array}$ & $\begin{array}{c}\text { Non-Likely } \\
\text { Buyers } \\
(\mathrm{N}=199)\end{array}$ & $\begin{array}{c}\text { Total } \\
(\mathrm{N}=290)\end{array}$ & \multirow{2}{*}{ Chi-Square } \\
\hline \multirow{2}{*}{ Are you...? } & Married & $55.6 \%$ & $43.9 \%$ & $47.6 \%$ & \multirow{2}{*}{.285} \\
\cline { 2 - 5 } & Living with a partner & $8.9 \%$ & $11.6 \%$ & $10.8 \%$ & \\
\cline { 2 - 5 } & Single & $33.3 \%$ & $42.9 \%$ & $39.9 \%$ & \\
\cline { 2 - 5 } & Widowed & $2.2 \%$ & $1.5 \%$ & $1.7 \%$ & \\
\hline
\end{tabular}


Table 9: Respondents with children at home.

\begin{tabular}{|l|l|c|c|c|c|}
\hline \multicolumn{2}{|c|}{} & $\begin{array}{c}\text { Likely } \\
\text { Buyers } \\
(\mathrm{N}=91)\end{array}$ & $\begin{array}{c}\text { Non-Likely } \\
\text { Buyers } \\
(\mathrm{N}=199)\end{array}$ & $\begin{array}{c}\text { Total } \\
(\mathrm{N}=290)\end{array}$ & Chi-Square \\
\hline $\begin{array}{l}\text { Do you have any children } \\
\text { under 18 living at home? }\end{array}$ & Yes & $28.4 \%$ & $24.6 \%$ & $25.8 \%$ & .500 \\
\cline { 2 - 5 } & No & $71.6 \%$ & $75.4 \%$ & $74.2 \%$ & \\
\hline
\end{tabular}

The data shows that the largest percentages of respondents have completed at least a college degree. These findings are shown below in Table 10. The proportion of college graduates in the sample is higher than the national MRI data. However, education does not impact purchase interest in Cal Poly Meat.

Table 10: Level of Education among respondents.

\begin{tabular}{|c|l|c|c|c|c|}
\hline \multicolumn{2}{|c|}{} & $\begin{array}{c}\text { Likely } \\
\text { Buyers } \\
(\mathrm{N}=91)\end{array}$ & $\begin{array}{c}\text { Non-Likely } \\
\text { Buyers } \\
(\mathrm{N}=199)\end{array}$ & $\begin{array}{c}\text { Total } \\
(\mathrm{N}=290)\end{array}$ & \multirow{2}{*}{ Chi-Square } \\
\hline \multirow{2}{*}{$\begin{array}{c}\text { What is the } \\
\text { level of } \\
\text { education } \\
\text { you have } \\
\text { completed? }\end{array}$} & Grade School or Less & - & $1.0 \%$ & $0.7 \%$ & \multirow{2}{*}{.528} \\
\cline { 2 - 5 } & Some High School & - & $.5 \%$ & $0.4 \%$ & \\
\cline { 2 - 5 } & High School Graduate & $12.8 \%$ & $7.7 \%$ & $9.3 \%$ & \\
\cline { 2 - 5 } & Some College & $25.6 \%$ & $27.7 \%$ & $27.0 \%$ & \\
\cline { 2 - 5 } & College Graduate & $45.3 \%$ & $50.8 \%$ & $49.1 \%$ & \\
\hline
\end{tabular}

Table 11 reports on the employment status of the individuals in the sample, by the considered groups. It was found that likely buyers are more likely to be employed full time (nearly three-fourths of the target consumers are employed full-time). 
Table 11: Employment Status of Individuals

\begin{tabular}{|c|l|c|c|c|c|}
\hline & & $\begin{array}{c}\text { Likely } \\
\text { Buyers } \\
(\mathrm{N}=91)\end{array}$ & $\begin{array}{c}\text { Non-Likely } \\
\text { Buyers } \\
(\mathrm{N}=199)\end{array}$ & $\begin{array}{c}\text { Total } \\
(\mathrm{N}=290)\end{array}$ & \multirow{2}{*}{ Chi-Square } \\
\hline \multirow{2}{*}{$\begin{array}{c}\text { Are you } \\
\text { employed? }\end{array}$} & Employed, Full Time & $70.9 \%$ & $57.9 \%$ & $62.0 \%$ & \multirow{2}{*}{$.058^{*}$} \\
\cline { 2 - 5 } & Employed, Part Time & $12.8 \%$ & $24.7 \%$ & $21.0 \%$ & \\
\cline { 2 - 5 } & Not Employed/ Retired & $16.3 \%$ & $17.4 \%$ & $17.0 \%$ & \\
\hline
\end{tabular}

*significant at the .10 level

Cal Poly meats products were most appealing to the annual household income of range $\$ 75,000$ to $\$ 140,000$. However, respondents falling in the income group of $\$ 25,000$ to $\$ 29,999$ were the least likely to be interested in purchasing Cal Poly meat products as seen in Table 12. These findings are concurrent with national MRI data found in Table 1, where the income group of $\$ 75,000$ to $\$ 149,000$ annual household income was the mostly likely to buy the mentioned meat products.

Table 12: Income levels of the respondents

\begin{tabular}{|c|c|c|c|c|c|}
\hline & & $\begin{array}{c}\text { Likely } \\
\text { Buyers } \\
(\mathrm{N}=91)\end{array}$ & $\begin{array}{c}\text { Non-Likely } \\
\text { Buyers } \\
(\mathrm{N}=199)\end{array}$ & $\begin{array}{c}\text { Total } \\
(\mathrm{N}=290)\end{array}$ & Chi-Square \\
\hline \multirow{10}{*}{$\begin{array}{l}\text { Which of the } \\
\text { following } \\
\text { ranges } \\
\text { describes your } \\
\text { household } \\
\text { income before } \\
\text { taxes? }\end{array}$} & Under $\$ 20,000$ & $4.8 \%$ & $12.7 \%$ & $10.3 \%$ & \multirow[t]{10}{*}{.584} \\
\hline & $\$ 20,000$ to $\$ 24,999$ & $3.6 \%$ & $4.8 \%$ & $4.4 \%$ & \\
\hline & $\$ 25,000$ to $\$ 29,999$ & $2.4 \%$ & $3.2 \%$ & $2.9 \%$ & \\
\hline & $\$ 30,000$ to $\$ 34,999$ & $6.0 \%$ & $3.2 \%$ & $4.0 \%$ & \\
\hline & $\$ 35,000$ to $\$ 39,999$ & $6.0 \%$ & $6.3 \%$ & $6.3 \%$ & \\
\hline & $\$ 40,000$ to $\$ 49,999$ & $8.4 \%$ & $8.5 \%$ & $8.5 \%$ & \\
\hline & $\$ 50,000$ to $\$ 59,999$ & $12.0 \%$ & $10.1 \%$ & $10.7 \%$ & \\
\hline & $\$ 60,000$ to $\$ 74,999$ & $15.7 \%$ & $14.8 \%$ & $15.1 \%$ & \\
\hline & $\$ 75,000$ to $\$ 149,999$ & $24.1 \%$ & $26.5 \%$ & $25.7 \%$ & \\
\hline & $\$ 150,000$ or more & $16.9 \%$ & $10.1 \%$ & $12.1 \%$ & \\
\hline
\end{tabular}

Results indicate that age has a significant impact on purchasers of Cal Poly meat products. More likely buyers of Cal Poly meat products were aged 40 years old and older (55 percent), compared to the non-target, 40 percent, as reported in Table 13. MRI 
plus data in Table 1 depicts similar findings, where the most likely purchasers' meat products are over 45 years of age.

Table 13: Age range of the respondents.

\begin{tabular}{|c|l|r|r|r|r|}
\hline \multicolumn{2}{|c|}{} & $\begin{array}{c}\text { Likely } \\
\text { Buyers } \\
(\mathrm{N}=91)\end{array}$ & $\begin{array}{c}\text { Non-Likely } \\
\text { Buyers } \\
(\mathrm{N}=199)\end{array}$ & $\begin{array}{c}\text { Total } \\
(\mathrm{N}=290)\end{array}$ & \multirow{2}{*}{ Chi-Square } \\
\hline \multirow{2}{*}{$\begin{array}{c}\text { Which of the } \\
\text { following ranges } \\
\text { describes your }\end{array}$} & 18 to 20 years old & $1.1 \%$ & $2.5 \%$ & $2.1 \%$ & \multirow{2}{*}{$.075 *$} \\
\cline { 2 - 5 } \begin{tabular}{c} 
age? \\
\cline { 2 - 5 }
\end{tabular} & 21 to 29 years old & $23.1 \%$ & $34.0 \%$ & $30.6 \%$ & \\
\cline { 2 - 5 } & 40 to 39 years old & $20.9 \%$ & $23.4 \%$ & $22.6 \%$ & \\
\cline { 2 - 5 } & 50 to 54 years old & $18.7 \%$ & $16.2 \%$ & $17.0 \%$ & \\
\cline { 2 - 5 } & 55 to 64 years old & $16.5 \%$ & $7.6 \%$ & $10.4 \%$ & \\
\cline { 2 - 5 } & $65+$ years old & $16.5 \%$ & $10.2 \%$ & $12.2 \%$ & \\
\hline
\end{tabular}

*significant at the .10 level

When examining consumer interest on Cal Poly meat products by the place of residence of the consumer, the results show (Table 14) that San Luis Obispo residents find Cal Poly meat products to be appealing. A third of the samples are residents from San Luis Obispo. It is interesting to note that respondents from all parts of the county are likely to purchase Cal Poly Meat if it is was sold in a store where they shop. Additionally, visitors to the region also find Cal Poly meat products to be appealing. 
Table 14: Where the respondents live.

\begin{tabular}{|c|c|c|c|c|c|}
\hline & & $\begin{array}{l}\text { Likely } \\
\text { Buyers } \\
(\mathrm{N}=91)\end{array}$ & $\begin{array}{c}\text { Non-Likely } \\
\text { Buyers } \\
(\mathrm{N}=199)\end{array}$ & $\begin{array}{c}\text { Total } \\
(\mathrm{N}=290)\end{array}$ & Chi-Square \\
\hline \multirow{12}{*}{$\begin{array}{c}\text { Where do you } \\
\text { live? }\end{array}$} & San Luis Obispo & $34.1 \%$ & $31.2 \%$ & $32.1 \%$ & \multirow[t]{12}{*}{.196} \\
\hline & Arroyo Grande & $14.3 \%$ & $8.5 \%$ & $10.3 \%$ & \\
\hline & Avila Beach & $2.2 \%$ & $2.0 \%$ & $2.1 \%$ & \\
\hline & Morro Bay & $9.9 \%$ & $13.6 \%$ & $12.4 \%$ & \\
\hline & Cambria & - & $.5 \%$ & $3.0 \%$ & \\
\hline & Cayucos & $1.1 \%$ & $2.5 \%$ & $2.1 \%$ & \\
\hline & Pismo Beach & $4.4 \%$ & $2.5 \%$ & $3.1 \%$ & \\
\hline & Grover Beach & $8.8 \%$ & $8.0 \%$ & $8.3 \%$ & \\
\hline & Nipomo & $3.3 \%$ & $.5 \%$ & $1.4 \%$ & \\
\hline & Atascadero & - & $5.0 \%$ & $3.4 \%$ & \\
\hline & Paso Robles & $6.6 \%$ & $12.1 \%$ & $10.3 \%$ & \\
\hline & Other & $15.4 \%$ & $13.6 \%$ & $14.1 \%$ & \\
\hline
\end{tabular}

In table 15, the data showed that all cities within the San Luis Obispo county area are equally as likely to have purchasers of Cal Poly Meats. To gain a better insight of where to market Cal Poly meat products, the cities were segregated into 3 regions: San Luis Obispo, Atascadero/Paso Robles, and Beach Cities/Nipomo as shown in Table 15. The Beach Cities/Nipomo group included: Arroyo Grande, Avila Beach, Morro Bay, Cambria, Cayucos, Pismo Beach, Grover Beach, and Nipomo. The data results show that San Luis Obispo and the Beach Cities/Nipomo are the two best regions to market Cal Poly Meats, whereas Atascadero/Paso Robles are not. 
Table 15: Likely Buyers of Cal Poly Meats by region.

\begin{tabular}{|l|c|c|c|c|}
\hline & $\begin{array}{c}\text { Likely } \\
\text { Buyers } \\
(\mathrm{N}=91)\end{array}$ & $\begin{array}{c}\text { Non-Likely } \\
\text { Buyers } \\
(\mathrm{N}=199)\end{array}$ & $\begin{array}{c}\text { Total } \\
(\mathrm{N}=290)\end{array}$ & \multirow{2}{*}{ Chi-Square } \\
\cline { 1 - 4 } San Luis Obispo & $40.3 \%$ & $36.0 \%$ & $37.3 \%$ & \multirow{2}{*}{$.058^{*}$} \\
\cline { 1 - 3 } Beach Cities/Nipomo & $51.9 \%$ & $44.2 \%$ & $46.6 \%$ & \\
\cline { 1 - 3 } Atascadero/Paso Robles & $7.8 \%$ & $19.8 \%$ & $16.1 \%$ & \\
\hline
\end{tabular}

*Significant at the .10 level

Purchasing Habits

Respondents were asked what type of meat products they have consumed at home in the last year. Respondents could choose from chicken, beef, pork, and other meat and select all that apply. Chicken was purchased by the highest proportion of consumers in the sample followed by beef, pork and other meats 1 as depicted in Table 16. These results are similar to Table $1 \mathrm{MRI}$ data results. MRI found that the most popular consumed meat in the US is chicken by 80 percent of the US population.

Table 16: Meat Purchasing Behavior.

\begin{tabular}{|c|l|c|c|c|c|}
\hline \multicolumn{2}{|c|}{} & $\begin{array}{c}\text { Likely } \\
\text { Buyers } \\
(\mathrm{N}=91)\end{array}$ & $\begin{array}{c}\text { Non-Likely } \\
\text { Buyers } \\
(\mathrm{N}=199)\end{array}$ & $\begin{array}{c}\text { Total } \\
(\mathrm{N}=290)\end{array}$ & Chi-Square \\
\hline $\begin{array}{c}\text { Which of the following } \\
\text { meat products have } \\
\text { you purchased for } \\
\text { consumption at home } \\
\text { in the last year? }\end{array}$ & Chicken & $95.6 \%$ & $97.5 \%$ & $96.9 \%$ & .391 \\
\cline { 2 - 6 } & Beef & $90.1 \%$ & $87.9 \%$ & $88.6 \%$ & .589 \\
\cline { 2 - 6 } & Other Meat & $73.6 \%$ & $72.4 \%$ & $72.8 \%$ & .822 \\
\hline
\end{tabular}

Likely buyers of Cal Poly Meats are also more likely to have purchased Cal Poly cheese and other Cal Poly food products (see Table 13). They are also less likely to have not purchased Cal Poly products. Table 14 shows likely buyers believe that Cal 
Poly food and wine products are high in quality rating them either as 'Excellent' or 'Very Good' in quality. These results show a strong brand equity for Cal Poly products.

Table 17: Cal Poly food and wine products purchased by respondents.

\begin{tabular}{|c|c|c|c|c|c|}
\hline & & $\begin{array}{l}\text { Likely } \\
\text { Buyers } \\
\text { ( } \mathrm{N}=91 \text { ) }\end{array}$ & $\begin{array}{l}\text { Non-Likely } \\
\text { Buyers } \\
(\mathrm{N}=199)\end{array}$ & $\begin{array}{c}\text { Total } \\
(\mathrm{N}=290)\end{array}$ & Chi-Square \\
\hline & $\begin{array}{l}\text { Fruits and/or } \\
\text { Vegetables }\end{array}$ & $33.0 \%$ & $25.1 \%$ & $27.6 \%$ & 166 \\
\hline purchased & Ice Cream & $22.0 \%$ & $20.1 \%$ & $20.7 \%$ & .714 \\
\hline following cal & Cheese & $40.7 \%$ & $30.7 \%$ & $33.8 \%$ & $.095 *$ \\
\hline Poly brand & Meats & $18.7 \%$ & $12.6 \%$ & $14.5 \%$ & .169 \\
\hline food or wine & Wine & $22.0 \%$ & $24.1 \%$ & $23.4 \%$ & .689 \\
\hline $\begin{array}{l}\text { products? } \\
\text { (mark all that }\end{array}$ & $\begin{array}{l}\text { Other Cal Poly Food } \\
\text { Products }\end{array}$ & $33.0 \%$ & $23.1 \%$ & $26.2 \%$ & $.077^{*}$ \\
\hline apply) & $\begin{array}{l}\text { I have not purchased } \\
\text { any Cal Poly brand } \\
\text { food or wine product }\end{array}$ & $24.2 \%$ & $37.7 \%$ & $33.4 \%$ & $.024^{* *}$ \\
\hline
\end{tabular}

**significant at the .05 level

*significant at the .10 level

Table 18: Cal Poly's food and wine products quality rating by respondents.

\begin{tabular}{|c|c|c|c|c|c|}
\hline & & $\begin{array}{l}\text { Likely } \\
\text { Buyers } \\
(\mathrm{N}=91)\end{array}$ & $\begin{array}{c}\text { Non-Likely } \\
\text { Buyers } \\
(\mathrm{N}=199)\end{array}$ & $\begin{array}{c}\text { Total } \\
(\mathrm{N}=290)\end{array}$ & Chi-Square \\
\hline \multirow{5}{*}{$\begin{array}{l}\text { How would you rate } \\
\text { Cal Poly food or } \\
\text { wine products on } \\
\text { the following } \\
\text { attribute, quality? }\end{array}$} & Excellent & $47.8 \%$ & $26.6 \%$ & $33.2 \%$ & \multirow[t]{5}{*}{$.004^{* *}$} \\
\hline & Very Good & $43.3 \%$ & $51.8 \%$ & $49.1 \%$ & \\
\hline & $\begin{array}{l}\text { Somewhat } \\
\text { Good }\end{array}$ & $8.9 \%$ & $20.1 \%$ & $16.6 \%$ & \\
\hline & Not Very Good & - & $1.0 \%$ & $0.7 \%$ & \\
\hline & Poor & - & $.5 \%$ & $0.3 \%$ & \\
\hline
\end{tabular}

**significant at the .05

level

Furthermore, over half of likely buyers of Cal Poly food and wine products believe that convenience to purchase of the products is 'Excellent' to 'Very Good' in convenience (Table 19). However, only 40 percent of non-likely buyers believe that convenience to purchase of the products is 'Excellent' to 'Very Good'. 
Table 19: Cal Poly's food and wine products convenience to purchase rating by respondents.

\begin{tabular}{|c|c|c|c|c|c|}
\hline & & $\begin{array}{l}\text { Likely } \\
\text { Buyers } \\
(\mathrm{N}=91)\end{array}$ & $\begin{array}{c}\text { Non-Likely } \\
\text { Buyers } \\
(\mathrm{N}=199)\end{array}$ & $\begin{array}{c}\text { Total } \\
(\mathrm{N}=290)\end{array}$ & Chi-Square \\
\hline \multirow{5}{*}{$\begin{array}{l}\text { How would you rate } \\
\text { Cal Poly food or } \\
\text { wine products on } \\
\text { the following } \\
\text { attribute, } \\
\text { convenience to } \\
\text { purchase? }\end{array}$} & Excellent & $23.3 \%$ & $14.7 \%$ & $17.4 \%$ & \multirow[t]{5}{*}{$.009 * *$} \\
\hline & Very Good & $31.1 \%$ & $24.9 \%$ & $26.8 \%$ & \\
\hline & $\begin{array}{l}\text { Somewhat } \\
\text { Good }\end{array}$ & $32.2 \%$ & $27.9 \%$ & $29.3 \%$ & \\
\hline & $\begin{array}{l}\text { Not Very } \\
\text { Good }\end{array}$ & $12.2 \%$ & $24.4 \%$ & $20.6 \%$ & \\
\hline & Poor & $1.1 \%$ & $8.1 \%$ & $5.9 \%$ & \\
\hline
\end{tabular}

$* *$ significant at the .05

level

When respondents were asked to rate the value of the products they buy for the cost associated with the product, three-fourths of the likely buyers of Cal Poly products believe the products are of excellent or very good value (Table 20). However, less than two-thirds of the non-likely buyers believe that the value of the product is 'Very Good'. The results in Tables 19 and 20 further support that brand quality is high among Cal Poly products.

Table 20: Cal Poly's food and wine products value for the money evaluation by the respondents.

\begin{tabular}{|c|c|c|c|c|c|}
\hline & & $\begin{array}{l}\text { Likely } \\
\text { Buyers } \\
(\mathrm{N}=91)\end{array}$ & $\begin{array}{c}\text { Non-Likely } \\
\text { Buyers } \\
(\mathrm{N}=199)\end{array}$ & $\begin{array}{c}\text { Total } \\
(\mathrm{N}=290)\end{array}$ & Chi-Square \\
\hline \multirow{5}{*}{$\begin{array}{l}\text { How would you rate } \\
\text { Cal Poly food or } \\
\text { wine products on } \\
\text { the following } \\
\text { attribute, value for } \\
\text { the money? }\end{array}$} & Excellent & $35.6 \%$ & $14.2 \%$ & $20.9 \%$ & \multirow[t]{5}{*}{$.000 * *$} \\
\hline & Very Good & $41.1 \%$ & $44.2 \%$ & $43.2 \%$ & \\
\hline & $\begin{array}{l}\text { Somewhat } \\
\text { Good }\end{array}$ & $21.1 \%$ & $35.5 \%$ & $31.0 \%$ & \\
\hline & Not Very Good & $2.2 \%$ & $6.1 \%$ & $4.9 \%$ & \\
\hline & Poor & - & - & - & \\
\hline
\end{tabular}

**significant at the .05 level 
Table 21 shows the location of where likely buyers and non-likely buyers shop for their meat products. Most consumers purchase their meat at a supermarket. However, the likely-buyer is less likely to purchase at a supermarket or farmers' market. The likely buyer is more likely to have purchased meat at other locations such as New Frontiers and Cal Poly's Meat Processing Center.

Table 21: Locations of meat purchases in San Luis Obispo County.

\begin{tabular}{|c|l|c|c|c|c|}
\hline \multicolumn{2}{|c|}{} & $\begin{array}{c}\text { Likely } \\
\text { Buyers } \\
(\mathrm{N}=91)\end{array}$ & $\begin{array}{c}\text { Non- } \\
\text { Likely } \\
\text { Buyers } \\
(\mathrm{N}=199)\end{array}$ & $\begin{array}{c}\text { Total } \\
(\mathrm{N}=290)\end{array}$ & $\begin{array}{c}\text { Chi- } \\
\text { Square }\end{array}$ \\
\hline $\begin{array}{c}\text { Over the past year, } \\
\text { where have you } \\
\text { purchased your meat } \\
\text { products? }\end{array}$ & $\begin{array}{l}\text { Chain grocery store } \\
\text { (Albertsons, Ralphs, Vons) }\end{array}$ & $78.0 \%$ & $86.4 \%$ & $83.8 \%$ & $.071^{*}$ \\
\cline { 2 - 6 } & Trader Joe's & $51.6 \%$ & $55.8 \%$ & $54.5 \%$ & .512 \\
\cline { 2 - 6 } & Costco & $51.6 \%$ & $60.3 \%$ & $57.6 \%$ & .166 \\
\cline { 2 - 6 } & New Frontiers & $34.1 \%$ & $24.6 \%$ & $27.6 \%$ & $.095^{*}$ \\
\cline { 2 - 6 } & Spencer's & $18.7 \%$ & $12.1 \%$ & $14.1 \%$ & .133 \\
\cline { 2 - 6 } & Farmer's Market & $15.4 \%$ & $24.6 \%$ & $21.7 \%$ & $.077^{*}$ \\
\cline { 2 - 6 } & Fresh \& Easy & $8.8 \%$ & $9.0 \%$ & $9.0 \%$ & .944 \\
\cline { 2 - 6 } & Restaurant & $14.3 \%$ & $6.0 \%$ & $8.6 \%$ & $.020^{* *}$ \\
\cline { 2 - 6 } & $\begin{array}{l}\text { Cal Poly's Meat Processing } \\
\text { Center }\end{array}$ & & $37.7 \%$ & $35.2 \%$ & .185 \\
\hline
\end{tabular}

*significant at the .10 level

**significant at the .05 level

The likely buyer spends more each month on meat. Table 22 shows a 26 percent difference of the likely buyer group and non-likely buyer that is spend on meat products during a monthly basis. The likely buyer group is likely to spent $\$ 126.74$ a month on average and/or is more likely to spend 26 percent more than the non-likely buyer group on meat products. 
Table 22: Approximate amount of money spent on meat products in a typical month by likely buyers and non-likely buyers groups.

\begin{tabular}{|c|c|c|c|}
\hline & $\begin{array}{c}\text { Likely Buyers } \\
(\mathrm{N}=91)\end{array}$ & $\begin{array}{c}\text { Non-Likely } \\
\text { Buyers } \\
(\mathrm{N}=199)\end{array}$ & P-Value \\
\hline $\begin{array}{c}\text { Approximately how much money do you spend } \\
\text { in a typical month on meat products? }\end{array}$ & 126.74 & 101.57 & $.018^{* *}$ \\
\hline
\end{tabular}

^Independent Sample t-test

**Significant at the .05 level

\section{Meat Attributes Consumers Desire}

To find what meat attributes customers desire, product positioning research is used. Product positioning refers to the process of identifying the most desirable attributes of a product and displaying them for the consumer to notice and purchase (Wolf, 2009).

The following statement was used to determine what attributes consumers are looking for: "The following is a list of features people may look for when purchasing meat. Please indicate the desirability of each feature to you purchasing meat." The statement was then rated on the resulting scale, where extremely desirable is a score of 5 , very desirable $=4$, somewhat desirable $=3$, slightly desirable $=2$, not at all desirable $=1$.

The attributes that were rated by the respondents were as follows; no hormones added, good value for the money, organic, not treated with antibiotics, natural, local brand, not fed animal by-products. The attributes listed were based on the topics of local vs. naturally produced meats products. 
In Table 19, the attributes of meat products were sorted in descending order by their mean rating, and a paired sample t-test was run to test for significant difference between attributes of the entire sample. It is important to note that all attributes chosen for this research were rated higher than 3, corresponding to 'somewhat desirable' level. 'Good value for the money' comes across as the top attribute rated by the respondents in this study and consumers rated it as a very desirable attribute. Below the 'Good value for the money' are the somewhat to very desirable attributes, 'No hormones added' which is more valued than 'Not treated with antibiotics'. However, the somewhat to very desirable attributes, 'not treated with antibiotics', 'Not fed animal by-products.', 'Natural', or 'Local brand' are also somewhat to very desirable attributes and consumers rate them to be the same level of desirability. At the bottom of the list, the sample values the 'local brand' attribute more than the 'organic' attribute.

Table 23: Total Respondents ranking on meat attributes.

\begin{tabular}{|l|c|c|}
\hline & $\begin{array}{c}\text { Mean } \\
(\mathrm{N}=293)\end{array}$ & P-Value^ $^{\wedge}$ \\
\hline Good value for the money & 4.32 & $.000^{* *}$ \\
\hline No hormones added & 3.96 & $.000^{* *}$ \\
\hline Not treated with antibiotics & 3.81 & .911 \\
\hline Not fed animal by-products & 3.79 & .160 \\
\hline Natural & 3.69 & .169 \\
\hline Local brand & 3.58 & $.025^{* *}$ \\
\hline Organic & 3.40 & \\
\hline
\end{tabular}

(5- Extremely Desirable, 4- Very Desirable, 3- Somewhat Desirable 2- Not Very Desirable ,1- Not Desirable at all)

^Paired Sample t-test

**Significant at the .05 level

A comparison of the attribute ratings between the likely and non-likely buyer groups, (Table 24) shows that the likely buyer rates all attributes except for 'Good Value 
for the Money' higher than the non-buyer group. The likely buyer is a higher spender on meat and also values the attributes examined here higher except for 'good value'.

Table 24: Difference between groups' value in meat attributes.

\begin{tabular}{|l|c|c|c|}
\cline { 2 - 3 } \multicolumn{1}{c|}{} & \multicolumn{2}{c|}{ Mean } \\
\hline & $\begin{array}{c}\text { Likely } \\
\text { Buyers } \\
(\mathrm{N}=91)\end{array}$ & $\begin{array}{c}\text { Non-Likely } \\
\text { Buyers } \\
(\mathrm{N}=199)\end{array}$ & \multirow{2}{*}{ P-Value $^{\wedge}$} \\
\hline Good value for the money & 4.30 & 4.31 & .897 \\
\hline No hormones added & 4.28 & 3.80 & $.000^{* *}$ \\
\hline Not treated with antibiotics & 4.22 & 3.63 & $.000^{* *}$ \\
\hline Not fed animal by-products & 4.07 & 3.66 & $.005^{* *}$ \\
\hline Natural & 3.91 & 3.57 & $.017^{* *}$ \\
\hline Local brand & 3.93 & 3.42 & $.000^{* *}$ \\
\hline Organic & 3.72 & 3.23 & $.001^{* *}$ \\
\hline
\end{tabular}

(5- Extremely Desirable, 4- Very Desirable, 3- Somewhat Desirable. 2- Not Very Desirable ,1- Not Desirable at all) ^Independent Sample t-test

**Significant at the .05 level

To determine how the likely buyer group exclusively rates the attributes, a paired sample t-test was run on their ratings. Table 25 , shows that none of the attributes show significant differences within the likely buyer group. The likely buyer group has determined they believe all the attributes list in Table 25 are of equal desirability.

Table 25: Attributes importance within the likely buyer group.

\begin{tabular}{|l|c|c|c|}
\hline & Likely Buyers N & Mean & P-Value $^{\wedge}$ \\
\hline Good value for the money & 91 & 4.31 & .844 \\
\hline No hormones added & 91 & 4.29 & .210 \\
\hline Not treated with antibiotics & 91 & 4.22 & .283 \\
\hline Not fed animal by-products & 91 & 4.08 & .207 \\
\hline Natural & 91 & 3.93 & .863 \\
\hline Local Brand & 91 & 3.91 & .113 \\
\hline Organic & 91 & 3.72 & \\
\hline
\end{tabular}

(5- Extremely Desirable, 4- Very Desirable, 3- Somewhat Desirable. 2- Not Very Desirable ,1Not Desirable at all)

^Paired Sample t-test

*Significant at the .10 level 


\section{Consumer Reaction to Cal Poly Meat Product Concept}

As discussed earlier, consumers were shown a priced concept of Cal Poly meat products and asked their likelihood to purchase them. Almost a third of the sample, 31.4 percent, indicated they were 'Certain Will to Almost Certain' to buy Cal Poly Meats if they were available in a store where they shop in the next twelve months, Table 6.

Respondents were shown the concept in figure 3. Respondents were then asked how they reacted to the prices shown on the concept board. At the time, all the prices were well above the supermarket prices. Whole chicken was priced 50 cents higher, flat irons were priced nearly 2 dollars higher, and the rib-eye steaks were about 3 dollars more than the supermarket prices. 
Figure 4: Example of Concept board.

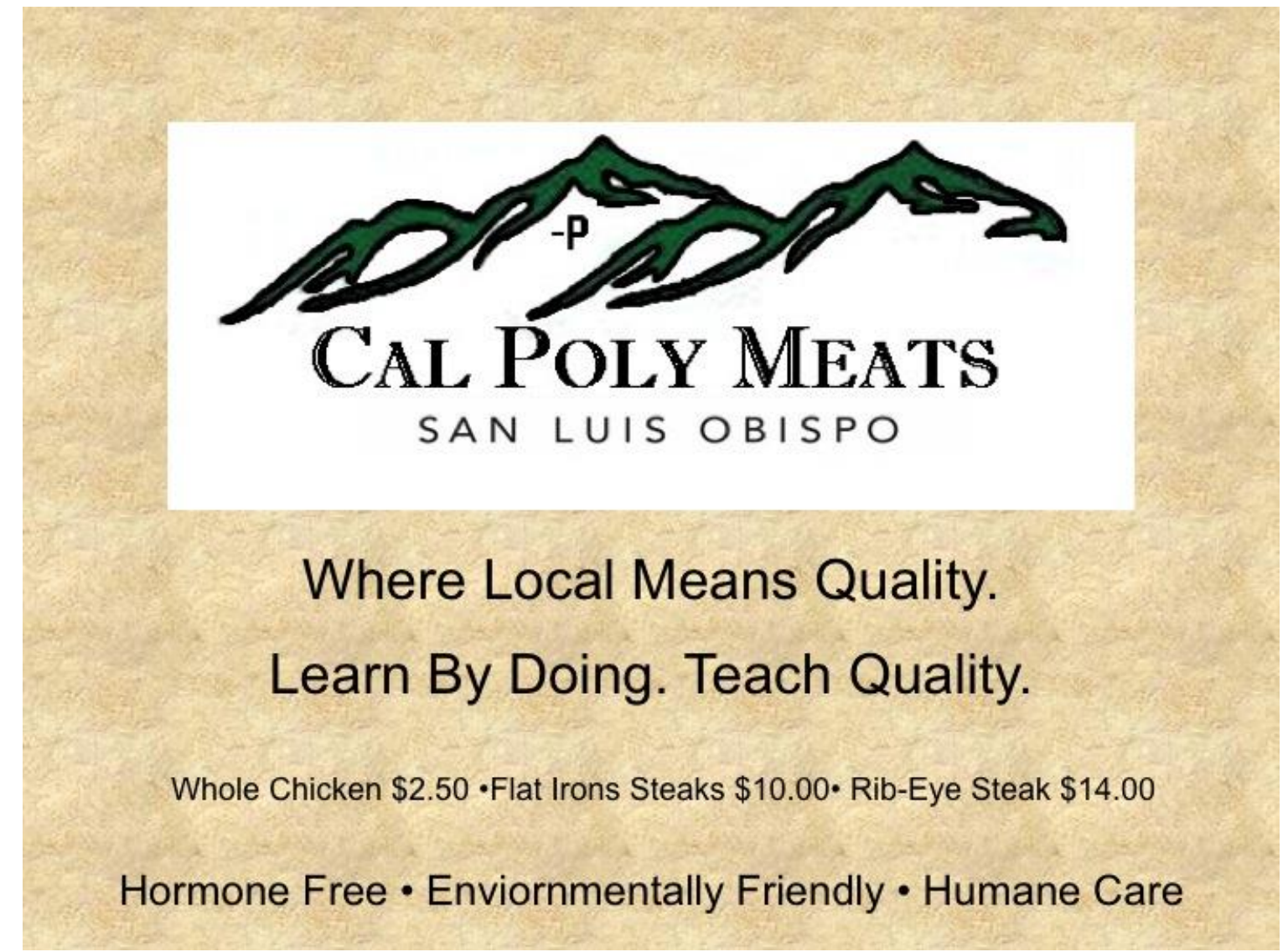

In Table 26, 74.4 percent of the likely buyer group indicated that the prices of the meat products on the concept board were 'just right' and results were statistically significant. Of the non-likely buyer group, 43.2 percent stated that they price of the meat products shown on the concept board were just right. This result clearly shows that price is an inhibitor to the non-likely buyer. Furthermore, the price rating combined with the lower ratings for Cal Poly products in Tables 14 through 16 explain why the non-likely buyer is not inclined to purchase Cal Poly meat. 
Table 26: Respondents price reaction to concept board.

\begin{tabular}{|c|l|c|c|c|c|}
\hline \multicolumn{2}{|c|}{} & $\begin{array}{c}\text { Likely } \\
\text { Buyers } \\
(\mathrm{N}=91)\end{array}$ & $\begin{array}{c}\text { Non-Likely } \\
\text { Buyers } \\
(\mathrm{N}=199)\end{array}$ & $\begin{array}{c}\text { Total } \\
(\mathrm{N}=290)\end{array}$ & Chi-Square \\
\hline \multirow{2}{*}{$\begin{array}{c}\text { Are the prices of the } \\
\text { products show on the } \\
\text { concept board...? }\end{array}$} & Too high & $21.1 \%$ & $43.2 \%$ & $36.3 \%$ & \multirow{2}{*}{$.001^{* *}$} \\
\cline { 2 - 5 } & Too low & $4.4 \%$ & $2.0 \%$ & $2.8 \%$ & \\
\cline { 2 - 5 } & Just right & $74.4 \%$ & $54.8 \%$ & $60.9 \%$ & \\
\hline
\end{tabular}

**Significant at the .05 level

Over half of the likely buyers are extremely or very likely to purchase Cal Poly meat at a farmers' market, table 27.

Table 27: Respondents involvement in local food initiatives.

\begin{tabular}{|c|l|c|c|c|c|}
\hline \multicolumn{2}{|c|}{} & $\begin{array}{c}\text { Likely } \\
\text { Buyers } \\
(\mathrm{N}=91)\end{array}$ & $\begin{array}{c}\text { Non-Likely } \\
\text { Buyers } \\
(\mathrm{N}=199)\end{array}$ & $\begin{array}{c}\text { Total } \\
(\mathrm{N}=290)\end{array}$ & \multirow{2}{*}{ Chi-Square } \\
\hline How likely are you \\
$\begin{array}{c}\text { to purchase a Cal } \\
\text { Poly meat product } \\
\text { at a local farmers' } \\
\text { market? }\end{array}$ & Extremely likely & $11.0 \%$ & $2.6 \%$ & $5.2 \%$ & \multirow{2}{*}{$.000 * *$} \\
\cline { 2 - 5 } & Very likely & $47.3 \%$ & $23.5 \%$ & $31.0 \%$ & \\
\cline { 2 - 5 } & Somewhat likely & $20.9 \%$ & $39.8 \%$ & $33.8 \%$ & \\
\cline { 2 - 5 } & Not very likely & $13.2 \%$ & $25.5 \%$ & $21.6 \%$ & \\
\hline
\end{tabular}

**Significant at the .05 level

In Table 28, respondents were asked to determine the likelihood of visiting Cal Poly Meats at the Cal Poly Meats Processing Center, if free parking was available. Over a third of the likely buyer was 'very likely' to 'extremely likely' to travel to the Cal Poly Meat Processing Center is free parking was available. 
Table 28: Likelihood of traveling to campus to purchase meat, if free parking was available.

\begin{tabular}{|c|c|c|c|c|c|}
\hline & & $\begin{array}{l}\text { Likely } \\
\text { Buyers } \\
(\mathrm{N}=91)\end{array}$ & $\begin{array}{c}\text { Non-Likely } \\
\text { Buyers } \\
(\mathrm{N}=199)\end{array}$ & $\begin{array}{c}\text { Total } \\
(\mathrm{N}=290)\end{array}$ & Chi-Square \\
\hline \multirow{5}{*}{$\begin{array}{l}\text { How likely are you to } \\
\text { go to the Cal Poly } \\
\text { campus to purchase } \\
\text { Cal Poly meats, if } \\
\text { there was free } \\
\text { parking available? }\end{array}$} & Extremely likely & $15.7 \%$ & $3.0 \%$ & $6.9 \%$ & \multirow[t]{5}{*}{$.000 * *$} \\
\hline & Very likely & $28.1 \%$ & $17.6 \%$ & $20.8 \%$ & \\
\hline & Somewhat likely & $28.1 \%$ & $32.7 \%$ & $31.3 \%$ & \\
\hline & Not very likely & $18.0 \%$ & $31.2 \%$ & $27.1 \%$ & \\
\hline & Not at all likely & $10.1 \%$ & $15.6 \%$ & $13.9 \%$ & \\
\hline
\end{tabular}

**Significant at the .05 level

\section{Local Significance}

Respondents were asked if they were involved in local food initiatives. Local food initiatives include but are not limited to, community sponsored agriculture (CSA), farmers' markets, U-picks, etc. A total of 38.9 percent of the likely buyer group stated that they were currently involved in local food initiatives. Table 26 displays the results of the respondent's involvement in local food initiatives.

Respondents were asked to define local to the best of their ability in terms of miles from home. Approximately three-fourths of the consumers indicate that 'local' is less than 50 miles from home.

Table 29: Defining local in the sense of miles from home.

\begin{tabular}{|c|l|c|c|c|c|}
\hline \multicolumn{2}{|c|}{} & $\begin{array}{c}\text { Likely } \\
\text { Buyers } \\
(\mathrm{N}=91)\end{array}$ & $\begin{array}{c}\text { Non-Likely } \\
\text { Buyers } \\
(\mathrm{N}=199)\end{array}$ & $\begin{array}{c}\text { Total } \\
(\mathrm{N}=290)\end{array}$ & \multirow{2}{*}{ Chi-Square } \\
\hline \multirow{2}{*}{$\begin{array}{c}\text { When thinking about } \\
\text { purchasing local food } \\
\text { products, how do you } \\
\text { define local? }\end{array}$} & $<10$ Miles & $6.7 \%$ & $10.6 \%$ & $9.4 \%$ & .332 \\
\cline { 2 - 5 } & $<30$ Miles & $43.8 \%$ & $31.3 \%$ & $35.2 \%$ & \\
\cline { 2 - 5 } & $<50$ Miles & $25.8 \%$ & $30.8 \%$ & $29.3 \%$ & \\
\cline { 2 - 5 } & $<100$ Miles & $19.1 \%$ & $18.7 \%$ & $18.8 \%$ & \\
\cline { 2 - 5 } & $100+$ Miles & $1.1 \%$ & $3.0 \%$ & $2.4 \%$ & \\
\cline { 2 - 5 } & I Don't Know & $3.4 \%$ & $5.6 \%$ & $4.9 \%$ & \\
\hline
\end{tabular}


Following the question on defining local in a mileage sense, respondents were then asked to define local in a regional sense rather than mileage (Table 30). Eighty-one percent of consumers indicated that the county or hometown defines local. However, likely buyers of Cal Poly meats stated that they were more likely to believe local in the locality sense to be defined as within their county and less likely to indicate town/city.

Table 30: Defining local in the sense of regions from home.

\begin{tabular}{|c|c|c|c|c|c|}
\hline & & $\begin{array}{l}\text { Likely } \\
\text { Buyers } \\
(\mathrm{N}=91)\end{array}$ & $\begin{array}{c}\text { Non-Likely } \\
\text { Buyers } \\
(\mathrm{N}=199)\end{array}$ & $\begin{array}{c}\text { Total } \\
(\mathrm{N}=290)\end{array}$ & Chi-Square \\
\hline \multirow{6}{*}{$\begin{array}{l}\text { When thinking } \\
\text { about purchasing } \\
\text { local food } \\
\text { products, do you } \\
\text { define local to be } \\
\text { from... }\end{array}$} & Your home town/city & $13.2 \%$ & $23.2 \%$ & $20.1 \%$ & \multirow[t]{6}{*}{$.017^{* *}$} \\
\hline & Your County & $75.8 \%$ & $54.0 \%$ & $60.9 \%$ & \\
\hline & Your State & $6.6 \%$ & $16.2 \%$ & $13.1 \%$ & \\
\hline & Western States & $1.1 \%$ & $.5 \%$ & $0.7 \%$ & \\
\hline & US & $1.1 \%$ & $3.0 \%$ & $2.4 \%$ & \\
\hline & I Don't Know & $2.2 \%$ & $3.0 \%$ & $2.8 \%$ & \\
\hline
\end{tabular}

$* *$ Significant at the .05 level

In order to have a clear definition of what local means, respondents were then asked to choose between the two previous definitions on how local is defined (Table 31). The majority of respondents (69.1 percent) stated that they believe locality means more to them when defining local.

Table 31: Representation of mileage or regions importance over the other.

\begin{tabular}{|c|c|c|c|c|c|}
\hline & & $\begin{array}{l}\text { Likely } \\
\text { Buyers } \\
(\mathrm{N}=91)\end{array}$ & $\begin{array}{c}\text { Non-Likely } \\
\text { Buyers } \\
(\mathrm{N}=199) \\
\end{array}$ & $\begin{array}{c}\text { Total } \\
(\mathrm{N}=290)\end{array}$ & Chi-Square \\
\hline \multirow{2}{*}{$\begin{array}{c}\text { What means more } \\
\text { to you when } \\
\text { deciding what local } \\
\text { is? }\end{array}$} & $\begin{array}{l}\text { Mileage (Set } \\
\text { Distance Away) }\end{array}$ & $28.7 \%$ & $31.8 \%$ & $30.9 \%$ & \multirow[t]{2}{*}{.604} \\
\hline & $\begin{array}{l}\text { Locality (City, } \\
\text { County, or State) }\end{array}$ & $71.3 \%$ & $68.2 \%$ & $69.1 \%$ & \\
\hline
\end{tabular}


In order to determine the importance of local foods to the individuals in the county, the following question was asked: "how important is it to you to purchase...," followed by a list of local foods: "local fruits, local vegetables, local meats, and local wines?" The respondents responded to the list of attributes by rating them on the resulting scale, where extremely important equals a score of 5 , very important $=4$, somewhat important $=3$, slightly important $=2$, not at all important $=1$.

Table 32 shows results regarding the importance of local products in consumers' decisions. The results show the total population and the importance of buying local products in descending order of the mean rating. The paired sample t-test result shows that the total sample population believes researching local vegetables and fruits are not only of the same importance, but are also more important than purchasing local meats; however, purchasing local meat is more important than purchasing local wines.

Table 32: Importance of local - total population.

\begin{tabular}{|c|l|c|c|}
\hline \multicolumn{2}{|l|}{} & $\begin{array}{c}\text { Likely } \\
\text { Buyers } \\
(\mathrm{N}=297) \\
\text { Mean }\end{array}$ & P-Value^ \\
\hline \multirow{2}{*|2}{$\begin{array}{c}\text { How important is it to you to } \\
\text { purchase...? }\end{array}$} & Local Vegetables & 3.81 & \\
\cline { 2 - 4 } & Local Fruits & 3.78 & .170 \\
\cline { 2 - 4 } & Local Meats & 3.42 & $.000^{* *}$ \\
\cline { 2 - 4 } & Local Wines & 3.13 & $.000^{* *}$ \\
\hline
\end{tabular}

(5- Extremely Important, 4- Very Important, 3- Somewhat Important. 2- Not Very Important ,1- Not Important at all)

$\wedge$ Paired Sample t-test

**Significant at the .05 level

When respondents were broken down into likely buyers and non-likely buyer groups, the rating of local products showed a difference. Table 33 shows the likely buyers of Cal Poly meat products place more importance on purchasing local 
vegetables, fruits, meats and wines than the non-likely buyer group. This data agrees with the likely buyer rating local brand higher.

Table 33: Importance of local food.

\begin{tabular}{|c|l|c|c|c|}
\hline \multicolumn{2}{|c|}{} & $\begin{array}{c}\text { Likely } \\
\text { Buyers } \\
(\mathrm{N}=91)\end{array}$ & $\begin{array}{c}\text { Non-Likely } \\
\text { Buyers } \\
(\mathrm{N}=199)\end{array}$ & P-Value^ \\
\hline \multirow{2}{*}{$\begin{array}{c}\text { How important } \\
\text { is it to you to } \\
\text { purchase...? }\end{array}$} & Local Vegetables & 4.10 & 3.65 & $.000^{* *}$ \\
\cline { 2 - 5 } & Local Fruits & 4.02 & 3.65 & $.004^{* *}$ \\
\cline { 2 - 5 } & Local Meats & 3.80 & 3.28 & $.000^{* *}$ \\
\cline { 2 - 5 } & Local Wines & 3.50 & 2.96 & $.000^{* *}$ \\
\hline
\end{tabular}

(5- Extremely Important, 4- Very Important, 3- Somewhat Important. 2- Not Very Important,1- Not Important at all)

$\wedge$ Paired Sample t-test

**Significant at the .05 level

To determine how the likely buyer group exclusively ranks local products, a paired sample t-test was run. Table 34, shows the likely buyer of Cal Poly meat products to have a hierarchy in purchasing of local products. Likely buyers believe that local vegetables are more important than local fruits and local meats and local wines.

Table 34: Likely buyers' importance of local products.

\begin{tabular}{|l|c|c|}
\hline & $\begin{array}{c}\text { Likely Buyers } \\
(\mathrm{N}=91) \\
\text { Mean }\end{array}$ & P-Value $^{\wedge}$ \\
\hline Local Vegetables & 4.10 & $.052^{*}$ \\
\hline Local Fruits & 4.02 & $.002^{* *}$ \\
\hline Local Meats & 3.80 & $.032^{* *}$ \\
\hline Local Wines & 3.50 & \\
\hline
\end{tabular}

(5- Extremely Important, 4- Very Important, 3- Somewhat Important. 2- Not Very Important ,1Not Important at all)

$\wedge$ Paired Sample t-test

**Significant at the 05 level

*significant at the .10 level 
The likely buyers of Cal Poly meat products are found to have a higher likelihood of being involved in local food initiatives. These results can be seen in Table 35.

Table 35: Involvement in local food initiatives

\begin{tabular}{|c|l|c|c|c|c|}
\hline \multicolumn{2}{|l|}{} & $\begin{array}{c}\text { Likely } \\
\text { Buyers } \\
(\mathrm{N}=91)\end{array}$ & $\begin{array}{c}\text { Non-Likely } \\
\text { Buyers } \\
(\mathrm{N}=199)\end{array}$ & $\begin{array}{c}\text { Total } \\
(\mathrm{N}=290)\end{array}$ & Chi-Square \\
\hline $\begin{array}{c}\text { Are you currently } \\
\text { involved in local food } \\
\text { initiatives (eg: CSA, } \\
\text { farmer's markets, etc.)? }\end{array}$ & Yes & $38.9 \%$ & $20.3 \%$ & $26.1 \%$ & \multirow{2}{*}{$.001^{* *}$} \\
\cline { 2 - 5 } & No & $61.1 \%$ & $79.7 \%$ & $73.9 \%$ & \\
\hline
\end{tabular}

**Significant at the .05 level

Lastly, the results in table 36 show the likely buyer group for Cal Poly meats is 'Certain likely' to 'almost surely' to purchase Cal Poly meats at a local farmers' market.

Table 36: Likelihood of likely Cal Poly meat buyers at a Farmers' Market.

\begin{tabular}{|c|l|c|c|c|c|}
\hline \multicolumn{2}{|l|}{} & $\begin{array}{c}\text { Likely } \\
\text { Buyers } \\
(\mathrm{N}=91)\end{array}$ & $\begin{array}{c}\text { Non-Likely } \\
\text { Buyers } \\
(\mathrm{N}=199)\end{array}$ & $\begin{array}{c}\text { Total } \\
(\mathrm{N}=290)\end{array}$ & \multirow{2}{*}{ Chi-Square } \\
\hline \multirow{2}{*}{$\begin{array}{c}\text { How likely are you to } \\
\text { purchase a Cal Poly } \\
\text { meat product at a local } \\
\text { farmers' market? }\end{array}$} & Extremely likely & $11.0 \%$ & $2.6 \%$ & $5.2 \%$ & \multirow{2}{*}{$.000^{* *}$} \\
\cline { 2 - 5 } & Very likely & $47.3 \%$ & $23.5 \%$ & $31.0 \%$ & \\
\cline { 2 - 5 } & Somewhat likely & $20.9 \%$ & $39.8 \%$ & $33.8 \%$ & \\
\cline { 2 - 5 } & Not at all likely & $7.7 \%$ & $8.7 \%$ & $8.4 \%$ & \\
\hline
\end{tabular}

**Significant at the .05 level

\section{Validation of Likely Buyer Group}

To determine the validity of the established likely buyer group that was determined earlier, a series of questions were re-analyzed with a new group were to find if any likely buyers were left out of the initial group. The new groups developed in table 37 were labeled 'Prospect Buyers'. The prospect buyers answered question 14 
(appendix A) within 80 percent, 'Very Probable Will Buy' to 70 percent 'Probable Will Buy' answer category. The group consisted of 95 potential buyers for Cal Poly Meats, keeping the Likely Buyer group with 91 buyers and reducing the non-Likely Buyer group down to 104 participants.

Table 37: Likely, Prospect, and Non-Likely Buyers of Cal Poly Meats.

\begin{tabular}{|c|c|c|c|}
\hline $\begin{array}{l}\text { How likely would you be to purchase in the } \\
\text { next year? }\end{array}$ & $\mathrm{N}$ & Percent & Grouping \\
\hline Certain Will Buy (99 chances in 100) & 40 & $13.8 \%$ & \multirow{2}{*}{$\begin{array}{l}\text { Likely Buyers } \\
\quad(\mathrm{N}=91)\end{array}$} \\
\hline Almost Sure Will Buy (90 chances in 100) & 51 & $17.6 \%$ & \\
\hline Very Probable Will Buy ( 80 chances in 100 ) & 55 & $19.0 \%$ & \multirow{2}{*}{$\begin{array}{l}\text { Prospect Buyers } \\
(\mathrm{N}=95)\end{array}$} \\
\hline Probable Will Buy (70 chances in 100) & 40 & $13.8 \%$ & \\
\hline Good Probably Will Buy (60 chances in 100) & 30 & $10.7 \%$ & \multirow{7}{*}{$\begin{array}{l}\text { Non-likely Buyers } \\
\qquad(\mathrm{N}=104)\end{array}$} \\
\hline Fairly Good Possibility Will Buy (50 chances in 100) & 26 & $9.0 \%$ & \\
\hline Fair Possibility Will Buy (40 chances in 100) & 15 & $5.2 \%$ & \\
\hline Some Possibility Will Buy (30 chances in 100) & 16 & $5.5 \%$ & \\
\hline Slight Possibility Will Buy (20 chances in 100) & 7 & $2.4 \%$ & \\
\hline Very Slight Possibility Will Buy (10 chances in 100) & 6 & $2.1 \%$ & \\
\hline No Chance You Will Buy (0 chances in 100$)$ & 3 & $1.0 \%$ & \\
\hline
\end{tabular}

Following the formation of the new group, the now three groups of buyers were analyzed by three questions to determine if the new prospect group could be incorporated into the likely buyer group and be an accurate indicator of future purchasers.

In table 38, the three groups were asked if they would visit Cal Poly meats on campus if free parking was available. The prospect buyers did showed that they were more likely than any of the others to be 'somewhat likely' to visit Cal Poly Meats on Campus. However these results do not reflect a higher likelihood than the Likely Buyer group showed of visiting Cal Poly meats on campus, so they could not be considered part of the likely buyer group. 
Table 38: Likely, Prospect, and Non-likely Buyers purchasing Cal Poly Meats on Campus.

\begin{tabular}{|c|c|c|c|c|c|c|}
\hline & & $\begin{array}{l}\text { Likely } \\
\text { Buyers } \\
(\mathrm{N}=91)\end{array}$ & $\begin{array}{c}\text { Prospect } \\
\text { Buyer } \\
(\mathrm{N}=95)\end{array}$ & $\begin{array}{l}\text { Non-Likely } \\
\text { Buyer } \\
(\mathrm{N}=194)\end{array}$ & $\begin{array}{c}\text { Total } \\
(\mathrm{N}=290)\end{array}$ & $\begin{array}{l}\text { Chi- } \\
\text { Square }\end{array}$ \\
\hline \multirow{5}{*}{$\begin{array}{l}\text { How likely are you } \\
\text { to go to the Cal } \\
\text { Poly campus to } \\
\text { purchase Cal Poly } \\
\text { meats, if there was } \\
\text { free parking } \\
\text { available? }\end{array}$} & Extremely Likely & $15.7 \%$ & $4.2 \%$ & $1.9 \%$ & $6.9 \%$ & \multirow[t]{5}{*}{$.001^{* *}$} \\
\hline & Very likely & $28.1 \%$ & $20.0 \%$ & $15.4 \%$ & $20.8 \%$ & \\
\hline & Somewhat likely & $28.1 \%$ & $34.7 \%$ & $30.8 \%$ & $31.3 \%$ & \\
\hline & Not very likely & $18.0 \%$ & $30.5 \%$ & $31.7 \%$ & $27.1 \%$ & \\
\hline & Not at all likely & $10.1 \%$ & $10.5 \%$ & $20.2 \%$ & $13.9 \%$ & \\
\hline
\end{tabular}

**Significant at the .05 level

Shown below in table 39, the prospect is not likely to visit a farmers market to purchase Cal Poly Meats. The prospect group drops off drastically in their individual contribution to the extremely and very likely likelihood to purchase at farmers' market as compared to the likely buyer group. This additional evidence does not show that the prospect group should be added to the likely buyer group.

Table 39: Likely, Prospect, and Non-likely Buyers at farmers markets.

\begin{tabular}{|c|c|c|c|c|c|c|}
\hline & & $\begin{array}{l}\text { Likely } \\
\text { Buyers } \\
\text { (N=91) }\end{array}$ & $\begin{array}{l}\text { Prospect } \\
\text { Buyer } \\
(\mathrm{N}=95)\end{array}$ & $\begin{array}{l}\text { Non- } \\
\text { Likely } \\
\text { Buyer } \\
(\mathrm{N}=194)\end{array}$ & $\begin{array}{c}\text { Total } \\
(\mathrm{N}=290)\end{array}$ & $\begin{array}{l}\text { Chi- } \\
\text { Square }\end{array}$ \\
\hline \multirow{5}{*}{$\begin{array}{l}\text { How likely are } \\
\text { you to purchase } \\
\text { a Cal Poly meat } \\
\text { product at a local } \\
\text { farmers' market? }\end{array}$} & $\begin{array}{l}\text { Extremely } \\
\text { Likely }\end{array}$ & $11.0 \%$ & $4.3 \%$ & $1.0 \%$ & $5.2 \%$ & \multirow[t]{5}{*}{$.000 * *$} \\
\hline & Very likely & $47.3 \%$ & $29.8 \%$ & $17.6 \%$ & $31.0 \%$ & \\
\hline & $\begin{array}{l}\text { Somewhat } \\
\text { likely }\end{array}$ & $20.9 \%$ & $43.6 \%$ & $36.3 \%$ & $33.8 \%$ & \\
\hline & Not very likely & $13.2 \%$ & $18.1 \%$ & $32.4 \%$ & $21.6 \%$ & \\
\hline & Not at all likely & $7.7 \%$ & $4.3 \%$ & $12.7 \%$ & $84.0 \%$ & \\
\hline
\end{tabular}

**Significant at the .05 level 
In table 40 , the three groups results are displayed to show the impression they had on the price of Cal Poly meats. The likely buyer group shows that Cal Poly meat products are priced just right as compared to the prospect group being the most individuals that think the price of Cal Poly Meat products are priced too high. Because of the prospect group believes the Cal Poly meats products were priced too high, they could not be added into the likely buyer group. The assessment of the prospect group showed that the right evaluation of the likely buyer group was correctly identified.

Table 40: Likely, Prospect, and Non-likely Buyers price impression on Cal Poly Meat Products.

\begin{tabular}{|c|c|c|c|c|c|c|}
\hline \multicolumn{2}{|c|}{} & $\begin{array}{c}\text { Likely } \\
\text { Buyers } \\
(\mathrm{N}=91)\end{array}$ & $\begin{array}{c}\text { Prospect } \\
\text { Buyer } \\
(\mathrm{N}=95)\end{array}$ & $\begin{array}{c}\text { Non- } \\
\text { Likely } \\
\text { Buyer } \\
(\mathrm{N}=194)\end{array}$ & $\begin{array}{c}\text { Total } \\
(\mathrm{N}=290)\end{array}$ & $\begin{array}{c}\text { Chi- } \\
\text { Square }\end{array}$ \\
\hline $\begin{array}{c}\text { Is the price } \\
\text { of these } \\
\text { products? }\end{array}$ & Too High & $21.1 \%$ & $35.8 \%$ & $50.0 \%$ & $36.3 \%$ & \multirow{2}{*}{$.000 * *$} \\
\cline { 2 - 6 } & Too Low & $4.4 \%$ & $0.0 \%$ & $3.8 \%$ & $2.8 \%$ & \\
\cline { 2 - 6 } & Just Right & $74.4 \%$ & $64.2 \%$ & $46.2 \%$ & $60.9 \%$ & \\
\hline
\end{tabular}

**Significant at the .05 level

Media

In table 41 , the respondents were asked to identify which sources of media they used to find out about their meat products. The total sample's most popular answer about finding out information on the meat they purchase was through friends and family followed by the meat department where they shopped. Perhaps Cal Poly can attract more consumers by informing personnel in the meat departments of stores about their product. Further, the Cal Poly Meat Processing Center should offer informational sessions to attract consumers and inform them about their products. It was found that the likely buyer group was less likely to use Google to find out about meat products. The least answered media source was QR codes, Twitter, and YouTube for the target group and Twitter for the non-target group. 
Table 41: Media channels that are recognized meat purchasers.

\begin{tabular}{|c|c|c|c|c|c|}
\hline & & $\begin{array}{l}\text { Likely } \\
\text { Buyers } \\
(\mathrm{N}=91)\end{array}$ & $\begin{array}{c}\text { Non-Likely } \\
\text { Buyers } \\
(\mathrm{N}=199)\end{array}$ & $\begin{array}{c}\text { Total } \\
(\mathrm{N}=290)\end{array}$ & Chi-Square \\
\hline \multirow{15}{*}{$\begin{array}{l}\text { Which of the } \\
\text { following do you } \\
\text { use to find } \\
\text { information } \\
\text { about meat? } \\
\text { (Choose all that } \\
\text { apply.) }\end{array}$} & Friends and Family & $60.4 \%$ & $60.8 \%$ & $60.7 \%$ & .953 \\
\hline & The Meat Department & $50.5 \%$ & $40.7 \%$ & $43.8 \%$ & .117 \\
\hline & Google & $20.9 \%$ & $33.2 \%$ & $29.3 \%$ & $.033 * *$ \\
\hline & Recipe Web Sites & $29.7 \%$ & $26.1 \%$ & $27.2 \%$ & .530 \\
\hline & Cooking Shows & $25.3 \%$ & $27.6 \%$ & $26.9 \%$ & .674 \\
\hline & Food Web Sites & $26.4 \%$ & $24.1 \%$ & $24.8 \%$ & .680 \\
\hline & Print Newspapers & $16.5 \%$ & $25.1 \%$ & $22.4 \%$ & .101 \\
\hline & Food Magazines Online & $19.8 \%$ & $14.1 \%$ & $15.9 \%$ & .217 \\
\hline & Blogs & $12.1 \%$ & $10.6 \%$ & $11.0 \%$ & .669 \\
\hline & Newspapers Online & $9.9 \%$ & $10.1 \%$ & $10.0 \%$ & .966 \\
\hline & Facebook & $8.8 \%$ & $8.0 \%$ & $8.3 \%$ & .829 \\
\hline & Radio & $2.2 \%$ & $6.0 \%$ & $4.8 \%$ & .158 \\
\hline & YouTube & $2.2 \%$ & $6.0 \%$ & $4.8 \%$ & .158 \\
\hline & QR Code & $2.2 \%$ & $3.0 \%$ & $2.8 \%$ & .693 \\
\hline & Twitter & $2.2 \%$ & $1.5 \%$ & $1.7 \%$ & .675 \\
\hline
\end{tabular}

**Significant at the .05 level 


\section{Chapter V}

Conclusion

Summary

The study investigates San Luis Obispo County meat purchasers. A total of 290 individuals were personally interviewed for attitudes of local meat products. The study closely looks at identifying the target meat buyers for Cal Poly meats, their perceptions of 'local' and their attitudes towards local products. Lastly, the study found the likely buyers of Cal Poly meats place a higher value of 'local' products.

Conclusion

Hypothesis one, the research accepts the null hypothesis: the target purchaser for local Cal Poly meat in San Luis Obispo County will be a heavier spender on meat and of older age. Based on the research presented earlier, the likely buyer of Cal Poly meats tends to spend nearly 20 percent more on meat products. The likely buyer of Cal Poly meats is, on average, to spend $\$ 126$ a month on meat products compared to the non-likely meat purchaser who is to spend nearly $\$ 101$ a month on meat products. The likely buyer of Cal Poly meats is a heavier spender than the non-likely buyer.

Additionally, the research found the likely-buyer of the Cal Poly Meats are to be of older age. It was found with significance is the likely purchasers are of 40 years of age or older. Further the non-likely buyer of Cal Poly Meats is younger than 40 years of age.

Hypothesis two, the researcher accepts the null hypothesis: The likely buyer for Cal Poly meats believes local foods to be important. 
The research results show that the likely buyer for Cal Poly Meats believes that local food is important through the analysis of several questions. The first evidence of how important local food is to the likely buyer is seen in question 9 (appendix A) about attributes of meat products. In the question's results, the likely buyer rated 'Local Brand' significantly higher than the non-likely buyers of Cal Poly Meats.

The second evidence of importance is seen when respondents were asked to rate local food products (question 14, appendix A). The likely-buyer group rated all the local food products higher in importance than the non-likely group. It shows that the likely buyer group places a higher importance on local foods.

Hypothesis three, the research accepts the null hypothesis: respondents will not define local as being in a set mileage radius from home, but rather in the vernacular sense by geographical boundaries.

Acceptance of the null hypothesis is based on questions 11,12 , and 13 (appendix A). Question 11 asked the respondents to define local by mileage; the statistical test showed no significance among the likely buyer group. Looking next at question 12, significance among likely buyers to preferred local to be defined in the geographical sense of within the county in which they reside.

Adding additional evidence to the concluded hypothesis, question 13 asked the respondents to select either mileage or geographical boundaries for the definition of local. The likely buyer group found at a significant level to define local as being within a geographical boundary, thus supporting the null hypothesis. 
Discussion

After looking at the entire data set and all statistical data results, the most prominent conclusion for Cal Poly Meats is to push Cal Poly branded meat products into stores within the county. An interesting observation was found when none of the cities came out to be a predominate location to sell Cal Poly Meats. However, with deeper thought and inspection, it seems that no matter where Cal Poly Meats is sold in the county it is likely as any other location to be bought by older residents.

Aiding in the push into stores is how respondents rated quality, value for the money, and convenience of purchase. The overall results for quality of Cal Poly product was rated 'Very Good to Excellent' among 70 percent of the respondents. Furthermore, 63 percent of respondents stated that the value they received for the money they spend on Cal Poly products was also 'Very Good to Excellent.'

A down side however, for Cal Poly Products was the convenience of purchase. Respondents rated convenience to purchase to be low, with 49 percent stating that convenience being 'Not very good to somewhat good."

These results indicate that Cal Poly products have high brand equity among customers but are hard for one to find the products. If Cal Poly was able to increase shelf space, a large market reach may be obtained.

\section{Future Research}

Moving forward in research of this field can be directed in several areas such as: willingness to pay for Cal Poly meat products and/or California definition of Local. Willingness to pay of Cal Poly meat products offers the opportunity to capture loss opportunity in price. More specifically the research could look at several products or a select species and the price for meat cuts. 
As seen in this study, local is an important attribute for meat products. Adding to the literature on local definition would benefit the ranching community of California. A growing percentage of ranchers are looking to create private labels and market their products. Research into what the entire state defines as local would be beneficial to the ranching and scholarly community. 


\section{Bibliography}

Abramson, J. H., \& Abramson, Z. H., (2008). Scales of Measurement, in Research Methods in Community Medicine: Surveys, Epidemiological Research, Programme Evaluation, Clinical Trials, Sixth Edition, John Wiley \& Sons, Ltd, Chichester, UK. doi: 10.1002/9780470987230.ch13.

Adams, D. C., \& Adams, A. E. (2011). De-placing local at the farmers' market: consumer conceptions of local foods. Journal of Rural Social Sciences (JRSS), 26(2), 74100.

Burros, M. (2007b). Preserving Fossil Fuels and Nearby Farmland by Eating Locally, The New York Times.

Brown, C. (2003). Consumers' preferences for locally produced food: A study in southeast Missouri. American Journal of Alternative Agriculture, 18(4), 213-224.

CDFA. (2014). California Department of Food and Agriculture. California Department of Food and Agriculture. Retrieved February 18, 2014, from http://www.cdfa.ca.gov/is/i_\&_c/cfm.html

Darby, K., Batte, M. T., Ernst, S., \& Roe, B. (2008). Decomposing Local: A Conjoint Analysis of Locally Produced Foods. American Journal of Agricultural Economics, 90(2), 476-486.

Franken, J. R., Parcell, J. L., \& Tonsor, G. T. (2011). Consumers' Willingness-to-Pay for Retail Branded Beef Products with Bundled Attributes. In Agricultural \& Applied Economics Association's 2011 AAEA \& NAREA Joint Annual Meeting, Pittsburgh, Pennsylvania, July (pp. 24-26).

Govindasamy, R., Zurbriggen, M., Italia, J., Adelaja, A., Nitzsche, P., \& Van Vranken, R. (1998). Farmers markets: Consumer trends, preferences, and characteristics. Parking, 52(28.3), 16-0.

Grannis, J., \& Thilmany, D. (2000). Marketing Opportunities For Natural Beef Products in the Intermountain West. Agricultural Marketing Report.

Hardesty, S. D. (2008). The Growing Role of Local Food Markets. American Journal of Agriculture Economics, 90, 1289-1295.

Harris, B., Burress, B., Mercer, S., Oslund, P., \& Rose, C. 2000. "Kaw Valley Focus Groups on Local and Organic Produce." Report No. 254B, Institute for Policy \& Social Research. Lawrence, KS: University of Kansas. Retrieved Febuary 5, 2014

Hartman. (2008, February 26). Consumer Understanding of Buying Local. <i>Hartman Group </i > . Retrieved February 11, 2014, from http://hartbeat.hartmangroup.com/article/220/Consumer-Understanding-of-Buying-Local

Hu, W. Y., Batte, M. T., Woods, T., \& Ernst, S. (2012). Consumer preferences for local production and other value-added label claims for a processed food product. 
European Review of Agricultural Economics, 39(3), 489-510. doi: 10.1093/erae/jbr039

Kerr. (2001) "Kerr Center Farmers Market Survey." Kerr Center Farmers Market Survey. Kerr Center, Web. 27 Feb. 2014.

Khan, F., \& Prior, C. (2010). Evaluating the urban consumer with regard to sourcing local food. International Journal of Consumer Studies, 34, 161-168. Retrieved February 10, 2014, from http://onlinelibrary.wiley.com/doi/10.1111/j.14706431.2009.00836.x/abstract

Martinez, S., Hand, M., Newman, C., Pra, M. D., Pollack, S., Ralston, K., et al. (2010). Local Food System. ERS. Retrieved February 6, 2014, from http://www.ers.usda.gov/publications/err-economic-research-report/err97/reportsummary.aspx

"MRI+: Welcome." MRI+: Welcome. Web. 27 Feb. 2014. <http://mriplus.com>.

Onken, K. A., Bernard, J. C., \& Pesek, J. D., Jr. (2011). Comparing willingness to pay for organic, natural, locally grown, and state marketing program promoted foods in the Mid-Atlantic region. In D. R. Just \& G. Blalock (Eds.), Agricultural and Resource Economics Review (Vol. 40, pp. 33-47): Northeastern Agricultural and Resource Economics Association.

Onianwa, O., Wheelock, G., \& Mojica, M. (2005). An Analysis of the Determinants of Farmer-to-Consumer Direct-Market Shoppers. Journal of food distribution research, 36(1).

Pirog, R. (2004). Consumer Perceptions of Locally Grown Foods and the Environmental \& Economic Impacts of Long --Distance Food Transport [PDF Document]. Retireved from Online Presentation Slides: http://www.nutrientdataconf.org/PastConf/NDBC28/Pirog.pdf

Satran, J. (2012, September 26). Local Produce Increasingly Preferred To Organic, Consumer Survey Shows. The Huffington Post. Retrieved April 9, 2014, from http://www.huffingtonpost.com/2012/09/26/local-produceorganic_n_1917485.html

Selfa, T., \& Qazi, J. (2005). Place, taste, or face-to-face? Understanding producerconsumer networks in "local" food systems in Washington State. Agriculture and Human Values, 22(4), 451-464.

Thilmany, D., Bond, C. A., \& Bond, K. J. (2008). Going local: Exploring Consumer Behavior and Motivations for Direct Food Purchases. (Vol. 90, pp. 1303-1309). American Journal of Agricultural Economics: Agricultural and Applied Economics Association.

Toler, S., Adams, D. C., Lusk, J. L., \& Briggeman, B. C. (2009). Fairness, FM, and Local Production [electronic resource]. American journal of agricultural economics, 91(5), 1272-1278. doi: http://dx.doi.org/10.1111/j.1467-8276.2009.01296.x

Umberger, W. J., Smith, A. R., \& Thilmany McFadden, D. D. (2009). Does altruism play 
a role in determining U.S. consumer preferences and willingness to pay for natural and regionally produced beef? [electronic resource]. Agribusiness, 25(2), 268-285. doi: http://dx.doi.org/10.1002/agr.20194

US Census. (2010). 2010 US Census. Retrieved February 11, 2014, from http://www.census.gov/2010census/

USDA-AMS. (2012, August 3). USDA Directory Records More Than 7,800 FM. USDA Directory Records More Than 7,800 FM | USDA Newsroom. Retrieved February 9, 2014, from http://www.usda.gov/wps/portal/usda/usdahome?contentid=2012/08/0262.xml

USDA-ERS. (2013, August 3). National Count of Farmers Market Directory Listing Graph: 1994-2013. Farmers Market and Local Food Systems. Retrieved February 6, 2014, from http://www.ams.usda.gov/AMSv1.0/ams.fetchTemplateData.do?template=Templ ateS\&navID=WholesaleandFarmersMarkets\&leftNav=WholesaleandFarmersMar kets\&page=WFMFarmersMarketGrowth\&description=Farmers\%20Market\%20Gr owth\&acct=frmrdirmkt

Voight, J. (2012, October 8). As Americans Rush to Fresh Food, Supermarket Chains Follow. CNBC.com. Retrieved January 23, 2014, from http://www.cnbc.com/id/49101716

Wolf, M., Spittler, A., \& Ahern, J. (2005). A Profile of Farmers' Market Consumers and the Perceived Advantages of Produce Sold at Farmers' Markets. Journal Of Food Distribution Research, 36(1), 192-201.

Wolf, M., \& Thulin, A. J. (2000a). A target consumer profile and positioning for promotion of a new locally branded beef product. Age, 18(21), 22-24.

Wolf, M., \& Thulin, A. J. (2000b). A target consumer profile and positioning for promotion of a new locally branded beef product. [Powerpoint]. Retrieved May 24, 2014.

Wilkins, J. L., Sobal, J. J., \& Bowdish, E. E. (2002). Consumer perceptions of seasonal and local foods: a study in a U.S. community. Ecology Of Food And Nutrition, 41(5), 415-439.

Zepeda, L., \& Leviten-Reid, C. (2004). Consumers' Views on Local Food. Journal of Food Distribution Research, 35(3). Retrieved February 10, 2014, from http://ageconsearch.umn.edu/bitstream/27 


\section{Appendix A}

\section{1.}

1. Which of the following meat products have you purchased for consumption at home in the last year?

$\begin{array}{ll}\square \text { chicken } & \square \text { Pork } \\ \square \text { Beef } & \square \text { other Meat }\end{array}$

Terminate if the respondent does not eat meat.

2. Have you ever purchased any of the following Cal Poly brand food or wine products? (mark all that apply)

$\square$ Frults andior Vegetables
$\square$ ice cream
$\square$ cheese
$\square$ Meats

$\square$ Wine

$\square$ other Cal Poly Food Products

$\square$ I have not purchased any Cal Poly brand food or wine products.

3. Even if you have not purchased Cal Poly food or wine products, based on your experience or perceptions, how would you rate Cal Poly brand food and wine products on the following?

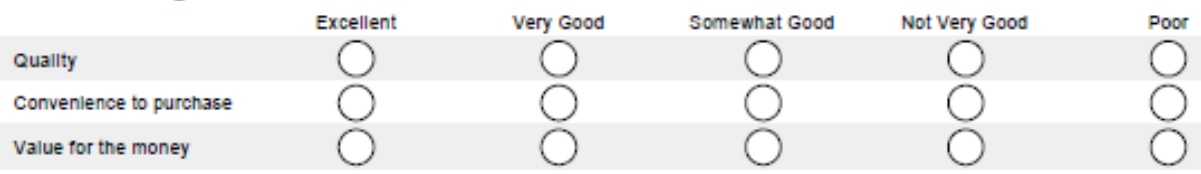

4. Over the past year, where have you purchased your meat products?
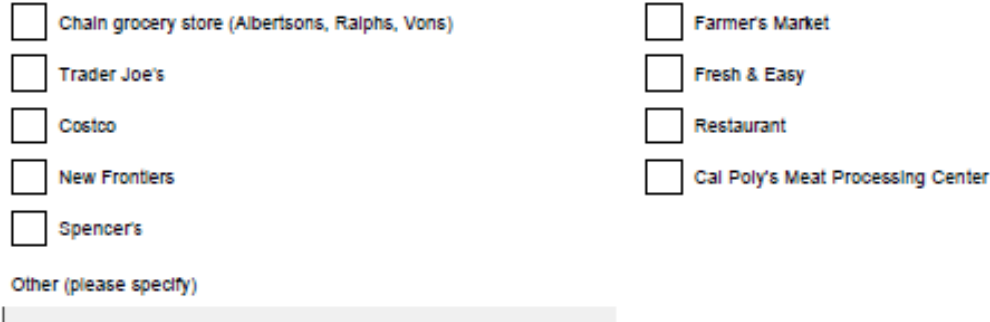

|

5. Approximately how much money do you spend in a typical month on meat products? 
6. Please think of the last hundred dollars you spent on meat, how much of it was spent on the following?

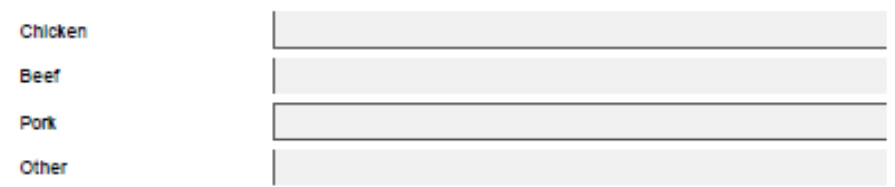

7. Of the number of times that you serve beef in a month, what percent is ground beef and what percent is steak/roasts? Example $\mathbf{5 0} \%$ Ground Beef, $\mathbf{5 0} \%$ Steaks/Roast or $\mathbf{1 0} \%$ Ground Beef, $90 \%$ Steaks/Roast

Ground beet

Steaks/ Roasts

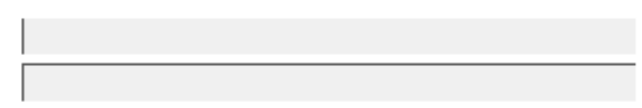

8. The following is a list of features people may look for when purchasing meat. Please indicate the desirability of each feature to you when you purchase meat.

Extremely Desirable, Very Desirable, Somewhat Desirable, Slightly Desirable, Not At All Desirable

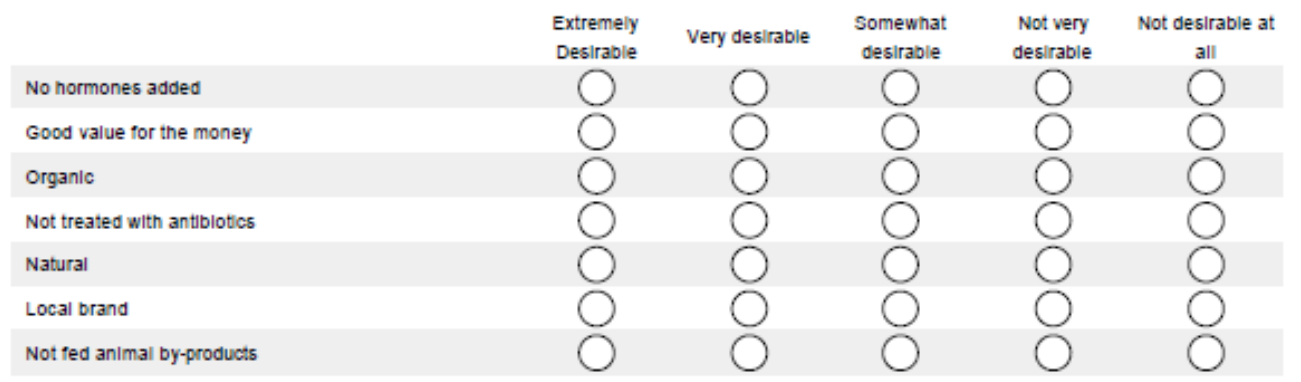

9. Are you currently involved in local food initiatives (eg: CSA, farmer's markets, etc.)?
Yes
No

10. When thinking about purchasing local food products, how do you define local?
○ 10 Miles
$\bigcirc<50$ Mlles
$100+$ Miles
O 30 Miles
O 100 Milles
I Don't know

11. When thinking about purchasing local food products, do you define local to be from...
Your home town/clty
Your state
$\bigcirc$ Your county
Western States
us
I Don't know

12. What means more to you when deciding what local is?
Mileage (Set dlstance away)
Locallty (City, county, or State) 


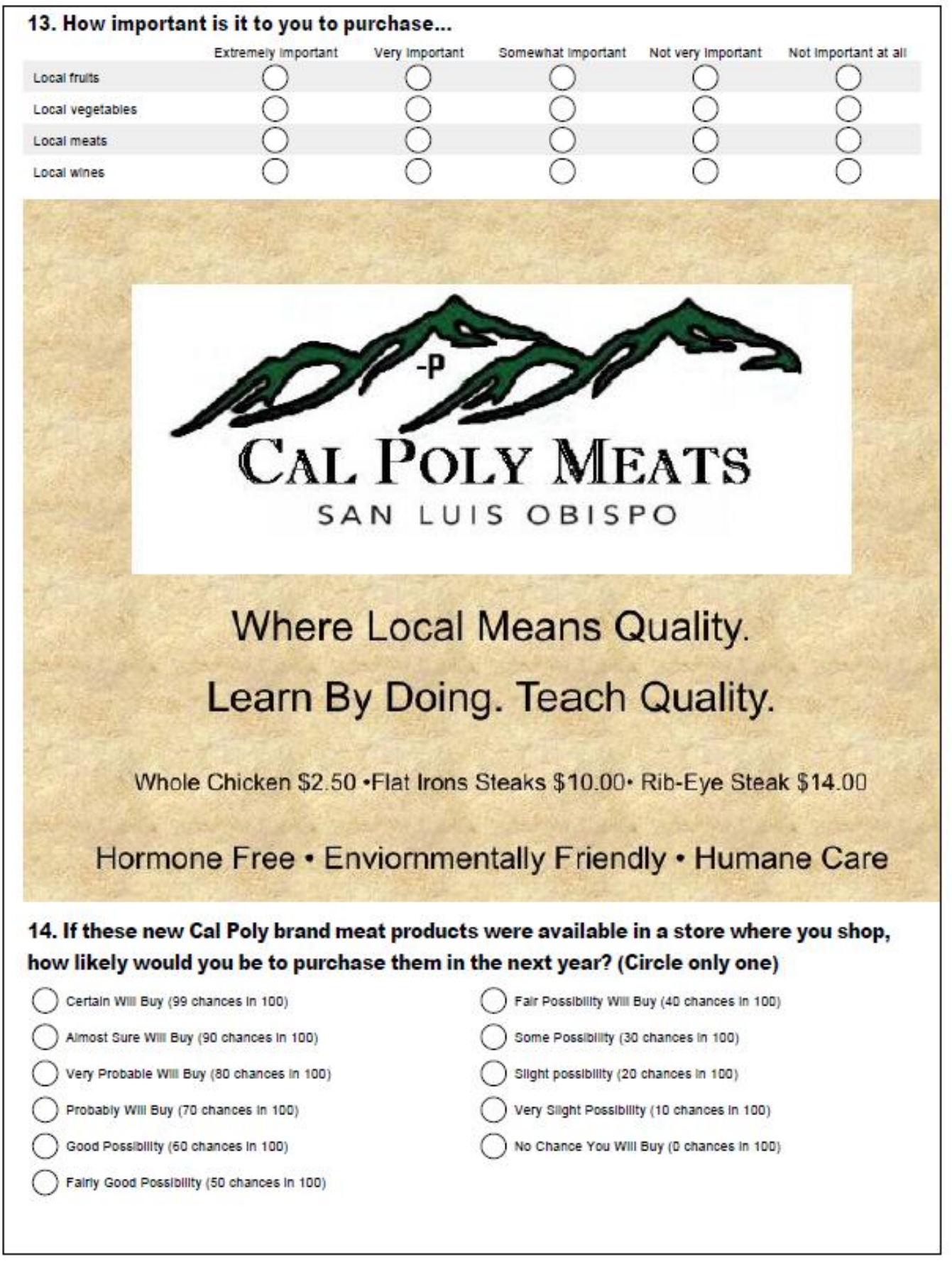


15. Is the price of these products?
Too high
Too low
Just right

16. How likely are you to purchase a Cal Poly meat product at a local farmers' market?
Extremely IIkely
very likely
somewhat llkely
Not very likely
Not at all Inkely

17. How likely are you to go to the Cal Poly campus to purchase Cal Poly meats, if there was free parking available?
Extremely $11 k e l y$
very likely
somewhat llikely
Not very likely
Not at all likely

18. Which of the following do you use to find information about meat? (Choose all that apply.)
$\square$ ㅂogs
$\square$ Print Newspapers
$\square$ Radlo
$\square$ QR code
$\square$ Google
$\square$ Newspapers Online
$\square$ YouTube
$\square$ Twitter
$\square$ Food Web sites
other (please speciry)

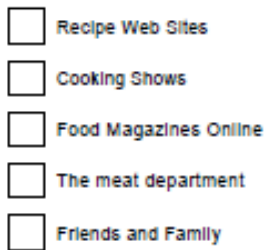

|

\section{Are you?}
Female
Male

20. Are you...
$\bigcirc$ Married
Lving with a partner
single
widowed

21. Do you have any children under 18 living at home? (Circle only one)

Yes

No

22. Please tell me the level of education you have completed. (Circle only one)
Grade School or Less
High School Graduate
college Graduate
some High school
some college
Post Graduate Work

23. Are you employed?
Employed, Full Time
Employed, Part Time
Not Employed/ Retred 
24. Which of the following ranges describes your age?

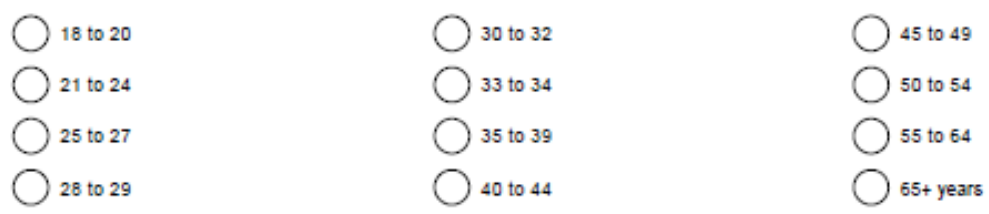

25. Where do you live?
San Luls Obispo
cambria
Nipomo
Arroyo Grande
cayucos
other
Avlla Beach
Plsmo Beach
Morro Bay
Grover Beach

26. Which of the following ranges describes your household income before taxes?
Under $\$ 20,000$
\$ $\$ 35,000$ to $\$ 39,999$
( $\$ 75,000$ to $\$ 149,999$
○20,000 to $\$ 24,999$
( 540,000 to $\$ 49,999$
$\$ 150,000$ or more
○ $\$ 25,000$ to $\$ 29,999$
( $\$ 50,000$ to $\$ 59,999$
○ $\$ 30,000$ to $\$ 34,999$
( 560,000 to $\$ 74,999$

27. Thank you! Please provide your email address so my professor can confirm that I completed this survey.

28. ID Number

ID 